\title{
NILAI KENYAMANAN RUANG TERBUKA HIJAU DI KOTA SURABAYA
}

\section{ANNISAULHAQ AMINSYAH}

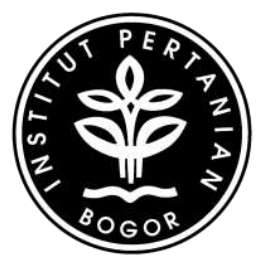

DEPARTEMEN KONSERVASI SUMBERDAYA HUTAN DAN EKOWISATA FAKULTAS KEHUTANAN INSTITUT PERTANIAN BOGOR BOGOR 2018 



\section{PERNYATAAN MENGENAI SKRIPSI \\ DAN SUMBER INFORMASI SERTA PELIMPAHAN HAK CIPTA *}

Dengan ini saya menyatakan bahwa skripsi Nilai Kenyamanan Ruang Terbuka Hijau di Kota Surabaya adalah benar karya saya dengan arahan dari komisi pembimbing dan belum diajukan dalam bentuk apa pun kepada perguruan tinggi mana pun. Sumber informasi yang berasal atau dikutip dari karya yang diterbitkan maupun tidak diterbitkan dari penulis lain telah disebutkan dalam teks dan dicantumkan dalam daftar pustaka di bagian akhir skripsi ini.

Dengan ini saya melimpahkan hak cipta dari karya tulis saya kepada Institut Pertanian Bogor.

Bogor, Sepetember 2018

Annisaulhaq Aminsyah 


\section{ABSTRAK}

ANNISAULHAQ AMINSYAH. Nilai Kenyamanan Ruang Terbuka Hijau di Kota Surabaya. Dibimbing oleh RACHMAD HERMAWAN dan YUDI SETIAWAN.

Kota Surabaya merupakan kota besar dengan tingkat pembangunan dan pertumbuhan penduduknya yang cepat. Mengimbangi pertambahan pemukiman dan fasilitas publik yang dibangun untuk masyarakat, maka pemerinntah Kota Surabaya membangun ruang terbuka hijau (RTH) demi meningkatkan kenyamanan melalui penyerapan $\mathrm{CO}_{2}$ dan penurunan suhu. Penelitian dilakukan di Taman Flora, Kebun Bibit Wonorejo, dan Hutan Kota Balas Klumprik. Pengambilan data suhu dan kelembapan dilakukan di 28 titik yang dipilih secara purposive sampling. Penelitian ini menunjukkan pengaruh yang signifikan perubahan suhu dan kelembapan terhadap perubahan jarak dari titik pusat RTH hingga titik terluar RTH. Suhu mengalami kenaikan 1-4 derajat dan kelembapan mengalami penurunan 2-17 \% keluar dari RTH. Kenyamanan termal di dalam, pinggir, dan luar RTH berada pada kondisi tidak nyaman. Hasil kuisioner kepada 30 pengunjung RTH didapatkan bahwa kondisi di dalam RTH termasuk nyaman. Perlu adanya penataan dan penambahan tanaman di dalam ruang terbuka hijau sehingga memberikan efek penurunan suhu dan peningkatan kelembapan.

Kata künci :kelembapan relatif, suhu, nilai kenyamanan.

\section{ABSTRACT}

ANNISAULHAQ AMINSYAH Comfort Value of Green Open Space in Surabaya City. Supervised by RACHMAD HERMAWAN and YUDI SETIAWAN.

The city of Surabaya is the big cities with a rapid level of development and population growth. Offsetting the increase in housing and public facilities built for the community, the City of Surabaya government built green open space (RTH) to increase comfort through $\mathrm{CO} 2$ absorption and temperature reduction. The study was conducted in Taman Flora, Kebun Bibit Wonorejo and Hutan Kota Balas Klumprik. The collection of temperature and humidity data was carried out at 28 points selected sampling purposively. This study found that significant effect of changes in temperature and relative humandity on changes in distance from the center point of the green open space to the outer point of green open space. The temperature has increased by 1-4 degrees and relative humidity has decreased from $2-17 \%$ out of green space. Thermal comfort at the inside, edge, and outside of the green open space is in an uncomfortable condition. The results of the questionnaire to $30 \mathrm{RTH}$ visitors found that the conditions in RTH were comfortable. It is necessary to arrange and to add more plants in a green open space reduce temperature reduction and increase relative humandity.

Keyword : comfort value, relative humandity, temperature. 
NILAI KENYAMANAN RUANG TERBUKA HIJAU

DI KOTA SURABAYA

ANNISAULHAQ AMINSYAH

Skripsi

Sebagai salah satu syarat untuk memperoleh gelar

Sarjana Kehutanan

Pada

Departemen Konservasi Sumberdaya Hutan dan Ekowisata

DEPARTEMEN KONSERVASI SUMBERDAYA HUTAN DAN EKOWISATA

FAKULTAS KEHUTANAN

INSTITUT PERTANIAN BOGOR

BOGOR

2018 



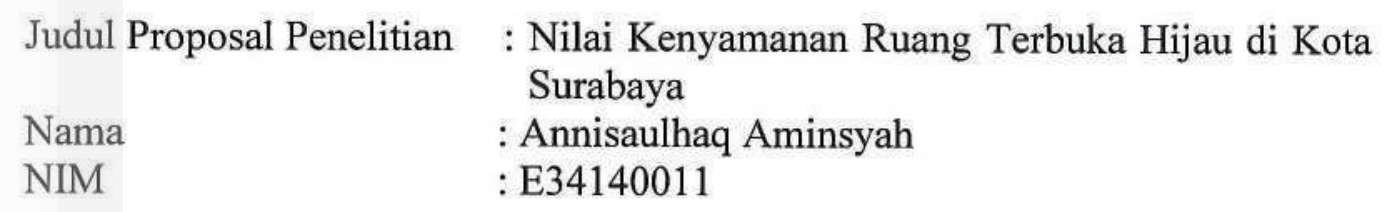

NIM

: Annisaulhaq Aminsyah

:E34140011

\section{Menyetujui, \\ Dosen Pembimbing}

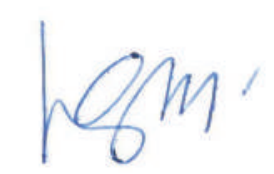

Dr. Ir. Rachmad Hermawan, MSc.F Pembimbing I

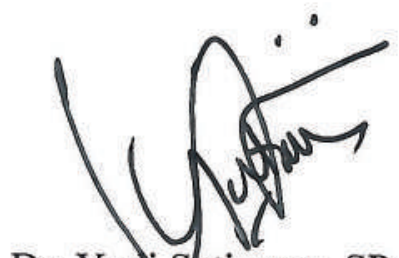

Dr. Yudi Setiawan, SP, M.Env.Sc Pembimbing II

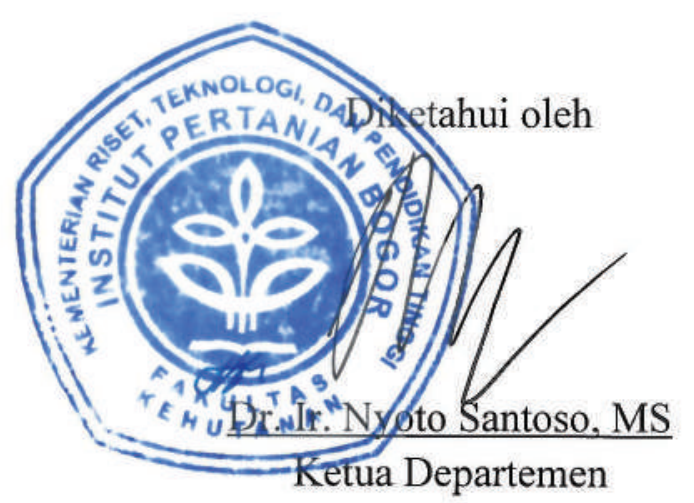

Tanggal Lulus: $\quad 12$ SFP $2 n+9$ 



\section{PRAKATA}

Puji syukur penulis panjatkan kepada Allah subhanallahu wa ta'ala atas segala karunia-Nya sehingga penulis dapat menyelesaikan karya ilmiah ini. Penelitian ini berjudul "Nilai Kenyamanan Ruang Terbuka Hijau di Kota Surabaya" yang akan dilaksanakan pada bulan Februari hingga April 2018.

Terima kasih penulis ucapkan kepada Bapak Dr. Ir. Rachmad Hermawan, MSc.Fdan Bapak Dr. Yudi Setiawan, SP, M.Env.Sc selaku dosen pembimbing yang telah memberikan masukan dan saran. Ungkapan terima kasih juga disampaikan kepada bapak, ibu, abang, dan buyung serta sahabat Ornithoptera croesus 51, teman sebimbingan, Tia, Laras, Putri, Citra, Ferri, Tika, Nilam dan Ade serta sahabat HIMAPARIS 51 terkhusus Ririn dan Hutri atas segala doa, kasih sayang dan dukungannya.

Semoga penelitian ini bermanfaat.

Bogor, September 2018

Annisaulhaq Aminsyah 



\section{DAFTAR ISI}

DAFTAR TABEL $\quad x$

DAFTAR GAMBAR $\quad$ X

DAFTAR LAMPIRAN

PENDAHULUAN 1

Latar Belakang 1

$\begin{array}{ll}\text { Perumusan masalah } & 2\end{array}$

Tujuan Penelitian 2

Manfaat Penelitian 3

Ruang Lingkup Penelitian 3

METODE PENELTIAN 3

Waktu dan Tempat 3

Alat dan Bahan 4

$\begin{array}{ll}\text { Jenis Data } & 4\end{array}$

Metode Pengumpulan Data 4

$\begin{array}{lr}\text { Analisis Data } & 8\end{array}$

$\begin{array}{ll}\text { HASIL DAN PEMBAHASAN } & 10\end{array}$

$\begin{array}{ll}\text { Kondisi Umum } & 10\end{array}$

Perbedaan Suhu dan Kelembapan di Dalam dan di Luar Ruang Terbuka

$\begin{array}{ll}\text { Hijau } & 12\end{array}$

Pengaruh Kerapatan Vegetasi dan LAI dengan Suhu dan Kelembapan di $\begin{array}{ll}\text { Ruang Terbuka Hijau } & 21\end{array}$

Analisis Nilai Kenyamanan Termal di Dalam dan di Luar Ruang Terbuka Hijau 25

Persepsi dan Preferensi Pengunjung Ruang Terbuka Hijau 27

Pengembangan Ruang Terbuka Hijau 30

SIMPULAN DAN SARAN

Simpulan $\quad 32$

$\begin{array}{ll}\text { Saran } & 33\end{array}$

DAFTAR PUSTAKA $\quad 34$

$\begin{array}{ll}\text { LAMPIRAN } & 37\end{array}$

RIWAYAT HIDUP 47 


\section{DAFTAR TABEL}

1 Metode Pengumpulan Data 4

2 Tekanan Berdasarkan Ketinggian $\quad 8$

3 Kriteria Tingkat kenyamanan $\quad 9$

4 Regresi Liniear sederhana Jarak dengan Suhu 12

5 Regresi Linear sederhana Jarak dengan Kelembapan 18

6 Nilai LAI Ruang Terbuka Hijau 22

7 Regresi linear sederhana antara LAI dengan suhu 24

8 Kerapatan vegetasi 25

\section{DAFTAR GAMBAR}

1 Peta Lokasi Penelitian 3

2 Titik Pengambilan data suhu dan kelembapan 5

3 Titik pengambilan data suhu Taman Flora 5

4 Titik pengambilan data suhu Kebun Bibit Wonorejo 6

5 Titik pengambilan data suhu Hutan Kota Balas Klumprik 6

6 Titik pengambilan data LAI (Leaf Area Index) 7

7 Perubahan suhu terhadap perubahan jarak Taman Flora 12

8 Peta perubahan suhu Taman Flora 14

9 Perubahan suhu terhadap perubahan jarak Kebun Bibit Wonorejo 15

10 Peta perubahan suhu Kebun Bibit Wonorejo 15

11 Perubahan suhu terhadap perubahan jarak Hutan Kota Balas 16 Klumprik

12 Peta perubahan suhu Hutan Kota Balas Klumprik 17

13 Peta perubahana kelembapan terhadap perubahan jarak Taman Flora 18

14 Peta perubahana kelembapan terhadap perubahan jarak Kebun Bibit 19 Wonorejo

15 Peta perubahana kelembapan terhadap perubahan jarak Hutan Kota 20 Balas Klumprik

16-LAI Taman Flora $\quad 22$

17СAI Kebun Bibit Wonorejo 23

18 LAI Hutan Kota Balas Klumprik 23

19 Hubungan LAI dengan suhu 24

20 Nilai THI di RTH 26

21 Vegetasi Hutan Kota Balas Klumprik 26 
22 Fungsi RTH 28

23 Tingkat kenyamanan menurut pengunjung 28

24 Pendapat pengunuung seberapa penting RTH 28

25 Preferensi pengunjung terkait elemen yang perlu ditambahkan 29

26 Penataan RTH yang diharapkan 30

27 Manfaat RTH yang diharapkan $\quad 30$

28 Sketsa penataan tanaman di RTH 32

\section{DAFTAR LAMPIRAN}

1 Kuisioner Terhadap Responden $\quad 37$

2 Identitas Responden 39

3 Kerapatan Taman Flora $\quad 39$

4 Kerapatan Kebun Bibit Wonorejo 40

5 Kerapatan Hutan Kota Balas Klumprik 40

6 Profil tajuk didalam RTH 41 



\section{PENDAHULUAN}

\section{Latar Belakang}

Wilayah perkotaan merupakan wilayah yang maju dengan pemusatan berbagai kegiatan ekonomi, sosial dan budaya. Berbagai kegiatan yang dilakukan di perkotaan mendorong pemerintah untuk menghadirkan fasilitas untuk menunjang kegiatan masyarakat di perkotaan tersebut. Selain bertambahnya bangunan untuk aktivitas publik, jumlah bangunan pemukiman ikut bertambah seiring banyaknya orang-orang yang berpindah ke perkotaan untuk memperbaiki kehidupan mereka. Pembangunan tersebut sebagian besar menyebabkan berkurangnya ruang terbuka hijau (RTH) di perkotaan. Keberadaan RTH yang semakin sedikit berakibat pada peningkatan suhu di perkotaan. Menurut Oliveira et al. (2011) bahwa perluasan wilayah di perkotaan berpengaruh terhadap kondisi perkoataan seperti berubahnya kondisi iklim mikro dan memburuknya kondisi lingkungan perkotaan. Parameter iklim mikro salah satunya adalah suhu dan kelembapan, semakin meningkatnya suhu di perkotaan dan menurunnya kelembapan berakibat pada penurunan tingkat kenyamanan di perkotaan. Hutan kota yang dibangun di dalam kota berfungsi menyejukkan udara kota, mengurangi kebisingan, menyerap dan menjerat debu. Membangun hutan kota secara maksimal di seluruh wilayah kota atau membangun kebun kota yang bernuansa hutan kota akan menciptakan lingkungan kota yang sejuk dan nyaman (Dahlan 2004).

Kota Surabaya merupakan salah satu kota besar yang ada di Indonesia dengan tingkat pembangunan dan pertumbuhan penduduknya yang cepat. Pertumbuhan penduduk dan pembangunan yang cepat ditandai dengan tersedianya aktivitas ekonomi yang memadai, tersedianya sarana komunikasi dan transportasi yang lengkap, serta sarana pendidikan dan kesehatan yang lengkap. Tingkat pertumbuhan yang bagus menjadikan Kota Surabaya menjadi salah satu tujuan migrasi bagi masyarakat. Kondisi ini mengakibatkan pertumbuhan Kota Surabaya menjadi pesat namun kondisi ini juga menjadikan teciptanya dan berlangsungnya pemukiman yang padat di perkotaan (Dyah et al. 2010). Mengimbangi penambahan jumlah penduduk yang diikuti oleh penambahan pemukiman dan fasilitas publik lainnya maka Pemerintah Kota Surabaya membangun Ruang Terbuka Hijau (RTH). Pembangunan RTH oleh pemerintah Kota Surabaya bertujuan untuk menyerap karbon dan menurunkan suhu di perkotaan sehingga akan meningkatkan kenyamanan. Menurut Informasi Kinerja Pengelolaan Lingkungan Hidup Daerah (IKPLHD) Kota Surabaya tahun 2016 Kota Surabaya saat ini mempunyai RTH seluas 7268.45 ha atau $21.73 \%$ dari total luas wilayah kota. Pengembalian RTH oleh Dinas Kebersihan dan Pertamanan Kota Surabaya selain memaksimalkan tanah kosong untuk dimanfaatkan menjadi RTH menghiasnya dengan tanaman dengan bunga warna-warni yang indah dan fungsional.

Vegetasi penyusun hutan kota dapat mengendalikan iklim mikro dengan cara menyerap panas sinar matahari dan memantulkannya sehingga terjadi penurunan suhu udara di dalam hutan kota (Tauhid 2008). Ruang terbuka hijau yang ditanami pepohonan membantu dalam penurunan suhu dan meningkatkan kelembapan sehingga dapat menciptakan kenyamanan. Pohon secara ekologis 
dapat membantu meningkatkan kualitas udara dengan menurunkan iklim mikro, menyerap air dan polutan udara (Sanger 2016). Pohon merupakan struktur vegetasi paling efektif memberikan kenyamanan iklim mikro bagi lingkungan sekitarnya (Ainy 2012). Hasil penelitian Aprihatmoko (2014) menunjukkan bahwa RTH jalur, RTH titik, wilayah tidak bervegetasi, dan RTH bervegetasi luas yaitu taman dan kebun binatang memiliki penurunan suhu yang berbeda, dimana rentang suhu suhu pagi hari $22,9{ }^{\circ} \mathrm{C}-25,6{ }^{\circ} \mathrm{C}$, siang hari sebesar $27,9{ }^{\circ} \mathrm{C}-35,3{ }^{\circ} \mathrm{C}$, dan sore hari sebesar $25,2{ }^{\circ} \mathrm{C}-28,5^{\circ} \mathrm{C}$ hasil tersebut menunjukkan bahwa kawasan RTH memiliki suhu udara yang rendah.

Menurut UU Republik Indonesia No 26 Tahun 2007 tentang Penataan Ruang, ruang terbuka hijau publik merupakan ruang terbuka hijau yang dimiliki dan dikelola oleh pemerintah daerah kota yang digunakan untuk kepentingan masyarakat umum. Ruang terbuka hijau public antara lain taman kota, taman pemakaman umum, jalur hijau sepanjang jalan, sungai, dan pantai. Selain memiliki fungsi ekologis dalam menjaga lingkungan perkotaan ruang terbuka hijau jüga memiliki fungsi sosial budaya antara lain sebagai ruang berkomunikasi dan berinteraksi, sarana rekreasi, olahraga, dan sarana pendidikan (Imansari et al. 2015). Ruang terbuka hijau (RTH) publik sering dikunjungi oleh masyarakat untuk itu perlu diperhatikan kenyamanan pengunjung. Vegetasi pohon adalah salah satu sumber rasa nyaman di dalam RTH karena memberikan suasana teduh dan sejuk. Berdasarkan hal tersebut maka dilakukan penelitian terkait keberadaan RTH terhadap penurunan suhu, peningkatan kelembapan dan indeks kenyamanan termal-di dalam maupun di luar RTH.

\section{Perumusan masalah}

Kota Surabaya merupakan salah satu kota terbesar di Indonesia yang $73.5 \%$ dari luas kotanya merupakan lahan terbangun menurut Informasi Kinerja Pengelolaan Lingkungan Hidup Daerah Kota Surabaya tahun 2016. Ketersediaan lahan terbangun tersebut diimbangi dengan adanya RTH yang dimiliki oleh Kota Surabaya. Ruang terbuka hijau tersebut berupa hutan kota, taman kota, pekarangan, jalur hijau, lapangan, kuburan, kebun, sawah, dan lainnya. Hal tersebut memunculkan beberapa pertanyaan, yaitu :

1. Apakah keberadaan RTH telah mampu menurunkan suhu dan meningkatkan kelembapan?

2. Bagaiamana hubungan tingkat kenyamanan termal dengan jarak dari titik pusat RTH?

3. Bagaimana persepsi pengunjung terhadap tingkat kenyamanan RTH?

\section{Tujuan Penelitian}

Tujuan penelitian ini adalah untuk mengkaji peran RTH dalam menurunkan suhu, meningkatkan kelembapan dan meningkatkan kenyamanan berdasarkan jarak titik pusat RTH. Selain itu, juga mengkaji persepsi pengunjung terhadap tingkat kenyamanan RTH. 



\section{Alat dan Bahan}

Alat yang digunakan dalam pengambilan data penelitian ini adalah termometer bola basah dan bola kering, tripod, kamera digital, meteran jahit, pita ukur, aquades, kompas, walking stick, GPS, pensil, pita, lensa fisheyes, panduan wawancara dan tallysheet. Software yang digunakan yaitu google earth, hemiview 2.1 digunakan untuk menganalisis tutupan tajuk, Microsoft Word, Microsoft excel, SExI-FS (Spatially Explicite Individual-based Forest Simulator) 2.1 digunakan untuk menggambarkan tegakan yang telah dilakukan analisisis vegetasi dan ArcGIS 10.3.

\section{Jenis Data}

Jenis data yang diambil dalam penelitian ini adalah data primer dan data sekunder (Tabel 1). Data primer merupakan data yang didapatkan langsung di lapang, dan data sekunder merupakan data yang didapatkan dari studi literatur berupa skripsi, tesis, jurnal dan buku.

Tabel 1 Jenis dan metode pengumpulan data

\begin{tabular}{|c|c|c|c|c|}
\hline No & Jenis Data & $\begin{array}{l}\text { Sifat } \\
\text { Data }\end{array}$ & $\begin{array}{c}\text { Metode } \\
\text { Pengumpulan } \\
\text { Data }\end{array}$ & Sumber Data \\
\hline 1 & $\begin{array}{l}\text { Kondisi umum } \\
\text { Jokasi } \\
\text { Ju } \\
\circ \\
0\end{array}$ & $\begin{array}{l}\text { Sekunder } \\
\text { dan } \\
\text { Primer }\end{array}$ & $\begin{array}{l}\text { Studi Pustaka dan } \\
\text { Pengamatan } \\
\text { Langsung }\end{array}$ & $\begin{array}{l}\text { Dinas Kebersihan } \\
\text { dan Ruang } \\
\text { Terbuka Hijau } \\
\text { (DKRTH) Kota } \\
\text { Surabaya dan } \\
\text { Lapang }\end{array}$ \\
\hline 2 & Kondisi Iklim & $\begin{array}{l}\text { Sekunder } \\
\text { dan } \\
\text { Primer }\end{array}$ & $\begin{array}{l}\text { Studi Pustaka dan } \\
\text { Pengukuran } \\
\text { langsung }\end{array}$ & $\begin{array}{l}\text { Badan } \\
\text { Meteorologi, } \\
\text { Klimatologi, dan } \\
\text { Geofisika (BMKG) } \\
\text { Kota Surabaya dan } \\
\text { Lapang }\end{array}$ \\
\hline 3 & $\begin{array}{l}\text { Data Vegetasi } \\
\text { meliputi : diameter } \\
\text { pohon, tinggi total } \\
\text { pohon, tinggi bebas } \\
\text { cabang pohon, jenis } \\
\text { pohon, lebar tajuk, } \\
\text { kerapatan tegakan }\end{array}$ & Primer & $\begin{array}{l}\text { Pengukuran } \\
\text { langsung }\end{array}$ & Lapang \\
\hline 4 & $\begin{array}{l}\text { LAI (Leaf Area } \\
\text { Index) }\end{array}$ & Primer & $\begin{array}{l}\text { Hemispherical } \\
\text { photograph }\end{array}$ & Lapang \\
\hline
\end{tabular}

\section{Metode Pengumpulan Data}

\section{Penetuan Lokasi Pengambilan Data}

Pengambilan data suhu dan kelembapan dilakukan di 28 titik yang dipilih secara purposive sampling. Metode penentuan titik secara purposive sampling 
yaitu penentuan plot dengan pertimbangan-pertimbangan tertentu. Titik 1 terletak ditengah RTH dengan pertimbangan sebagai pusat RTH dengan asumsi memiliki kerapatan vegetasi yang tinggi, empat titik teletak di antara tengah dan pinggir RTH, empat titik di luar RTH. Terdapat empat titik di luar hutan kota dengan interval jarak pengukuran $25 \mathrm{~m}$ atau $50 \mathrm{~m}$ mengikuti kondisi lapang $(25 \mathrm{~m}, 50 \mathrm{~m}$, $75 \mathrm{~m}, 100 \mathrm{~m}$ atau $50 \mathrm{~m}, 100 \mathrm{~m}, 150 \mathrm{~m}, 200 \mathrm{~m}$ ) sebanyak empat transek (Gambar $2,3,4$, dan 5).

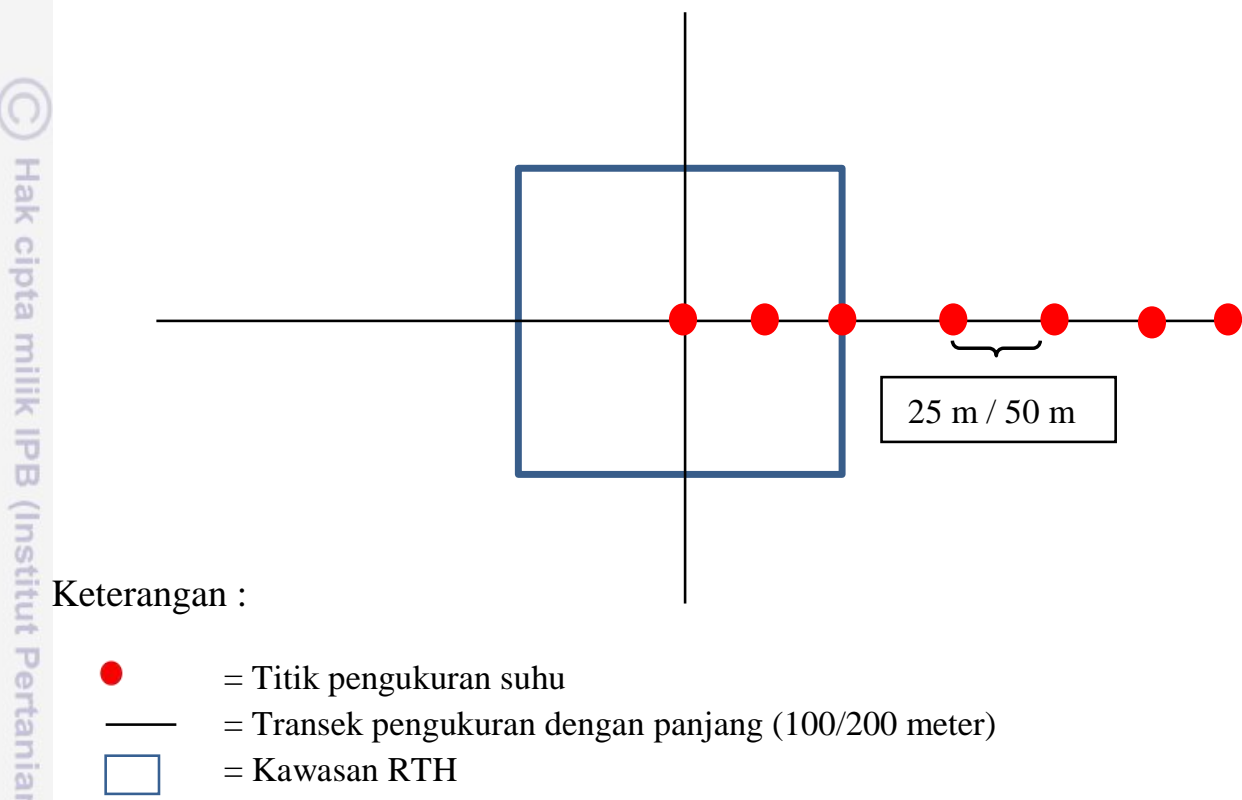

Gambar 2 Titik pengambilan data suhu dan kelembapan

Pengukuran suhu terhadap Taman Flora dilakukan sebanyak 4 transek. Titik pengukuran suhu di dalam Taman Flora sebanyak 12 titik dari pusat Taman Flora hingga ke pinggir. Titik pengukuran suhu di luar Taman Flora sebanyak 16 titik seperti terlihat pada Gambar 3.

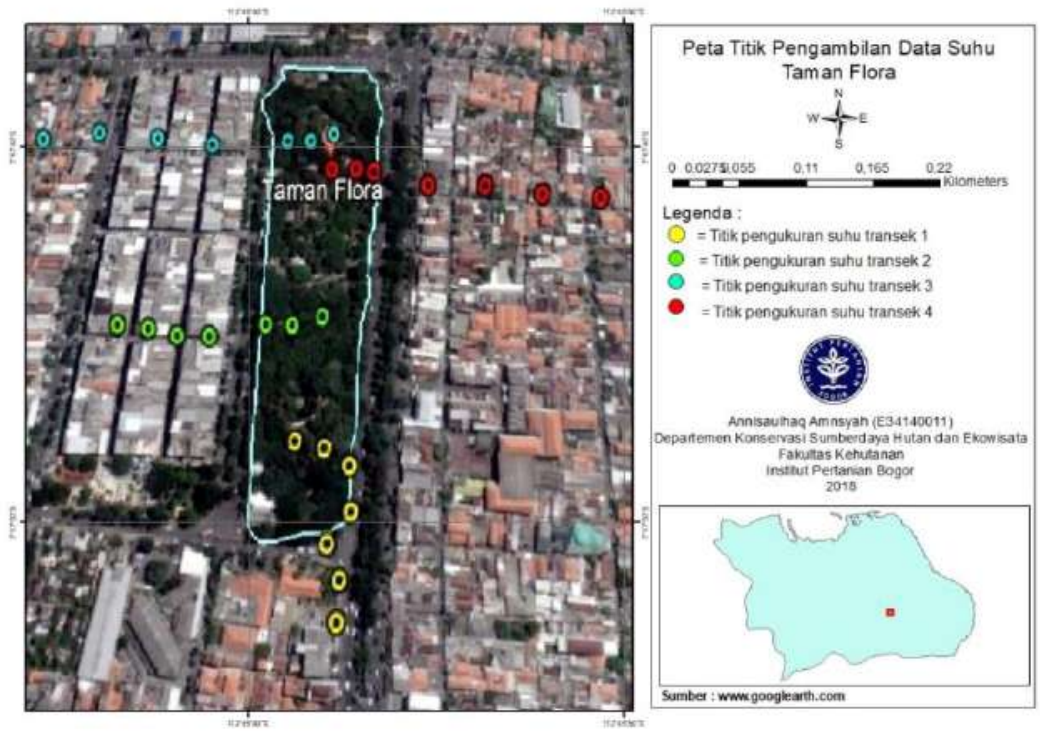

Gambar 3 Titik pengambilan data suhu Taman Flora 
Pengukuran suhu terhadap Kebun Bibit Wonorejo dilakukan sebanyak 24 titik yang berada di dalam dan di luar Kebun Bibit Wonorejo. Pengukuran tersebut dibagi menjadi 4 transek, terdapat 11 titik pengukuran suhu yang berada di dalam Kebun Bibit Wonorejo dari pusat hingga pinggir Kebun Bibit Wonorejo. Pengukuran suhu di luar Kebun Bibit Wonorejo sebanyak 14 titik sebaran titik pengukuran suhu terdapat pada Gambar 4.

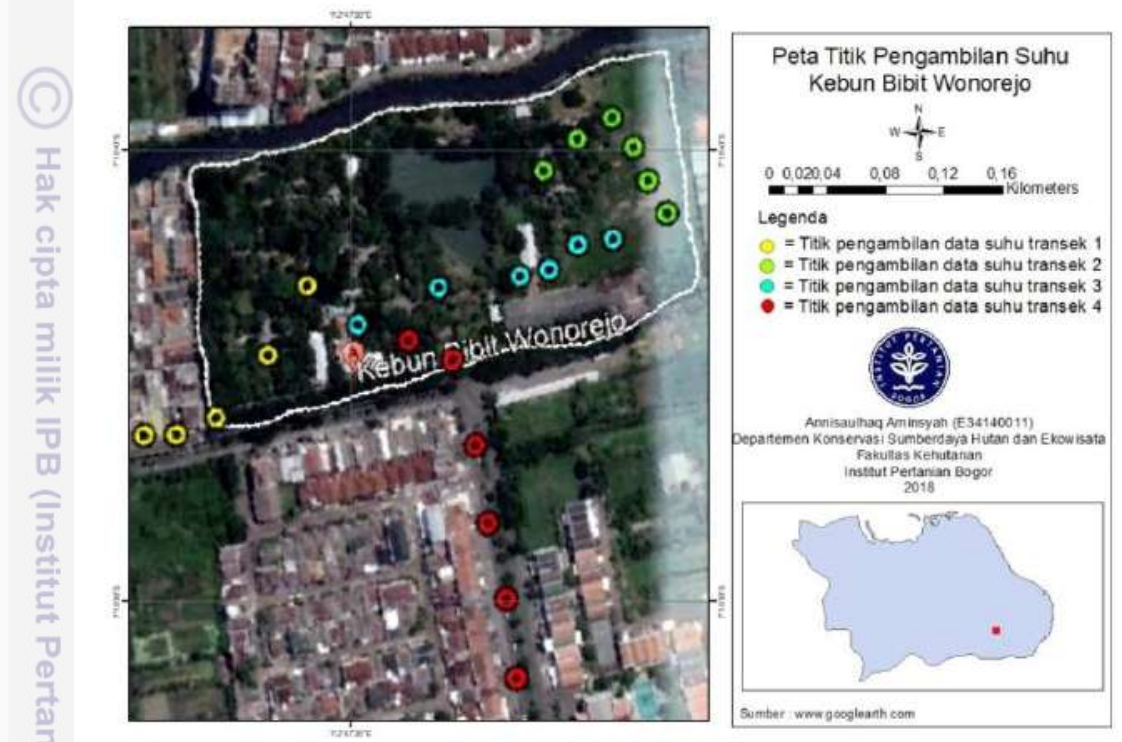

Gambar 4 Titik pengambilan data suhu Kebun Bibit Wonorejo

Pengukuran suhu di Hutan Kota Balas Klumprik dilakukan sebanyak 28 titik yang tersebar dari dalam hingga keluar Hutan Kota Balas Klumprik. Pengukuran di dalam Hutan Kota Balas Klumprik sebanyak 12 titik dari titik pusat hingga pinggir Hutan Kota Balas Klumprik. Pengukuran di luar Hutan Kota Balas Klumprik sebanyak 16 titik, titik pengukuran suhu seperti terdapat pada Gambar 5.
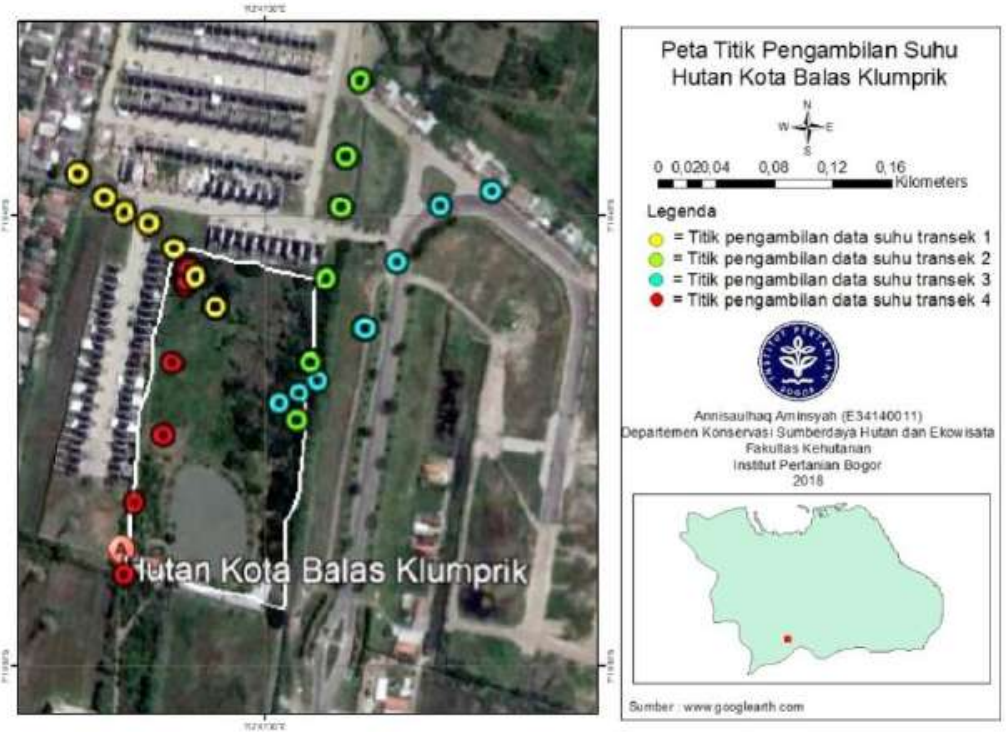

Gambar 5 Titik pengambilan data suhu Hutan Kota Balas Klumprik 


\section{Pengambilan Data Primer}

Pengukuran suhu dilakukan sebanyak tiga kali dalam sehari yaitu pada pagi shari pukul 07.00-08.00 WIB, siang hari pukul 13.00-14.00 WIB, dan pada sore hari pukul 16.00-17.00 WIB. Pengulangan terhadap pengukuran suhu dilakukan sebanyak tiga kali. Nilai kelembapan didapatkan dari pengolahan data suhu bola basah, bola kering, dan ketinggian lokasi penelitian diatas permukaan laut menggunakan rumus dari Abbott et al.(1985).

Pengambilan data vegetasi dilakukan dengan analisis vegetasi untuk mengetahui komposisi suatu komunitas suatu tegakan. Metode yang digunakan adalah metode petak contoh dengan membuat plot contoh berukuran $20 \mathrm{~m} \times 20 \mathrm{~m}$, dimana plot $20 \mathrm{~m}$ x $20 \mathrm{~m}$ dilakukan analisis vegetasi untuk tingkat pohon, $10 \mathrm{~m} \mathrm{x}$ $10 \mathrm{~m}$ untuk tingkat tiang, $5 \mathrm{~m} \times 5 \mathrm{~m}$ pengamatan untuk pancang dan $2 \mathrm{~m} \times 2 \mathrm{~m}$ tumbuhan tingkat semai. Parameter pengukuran pohon dan tiang adalah tinggi total (Tt), Tinggi bebas cabang (Tbc), dimaeter (Dbh), dan luas proyeksi tajuk.

Pengukuran terhadap LAI dilakukan di dalam RTH dan bagian pinggir RTH (Gambar 6). Pengambilan LAI menggunakan alat Hemisphericalview canopy analyzer. Alat diletakkan pada tripod dengan ketinggian $1 \mathrm{~m}$, diposisikan alat mengahadap keutara. Menurut Djumhaer (2003) pengambilan foto dilakukan pada sore hari atau kondisi mendung, hal ini memiliki tujuan untuk menghindari difraksi matahari yang berakibat timbulnya bayangan pada foto sehingga foto sukar untuk dianalisis.

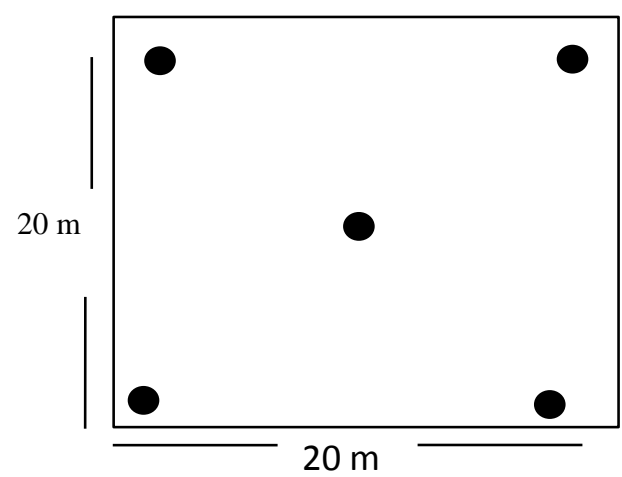

Gambar 6 Titik pengambilan data LAI (Leaf Area Index)

Pengambilan data wawancara ke pengunjung dilakukan untuk mengetahui pendapat pengunjung terkait keberadaan RTH di Kota Surabaya. Wawancara untuk mengetahui pengaruh keberadaan RTH terhadap rasa nyaman yang dirasakan oleh pengunjung dengan mengisi kuisioner (Lampiran 1). Wawancara dilakukan kepada 30 responden yang berada di RTH. Penentuan jumlah responden 30 orang mengacu pada Roscoe (1982) dalam Sugiyono (2011) bahwa ukuran sampel yang layak dalam penelitian adalah 30 sampel. Jumlah 30 merupakan jumlah sampel minimum dalam penelitan. Metode yang digunakan dalam pemilihan responden ialah accidental sampling dimana penentuan sampel responden berdasarkan kebetulan/insidental bertemu dengan peneliti dan dapat digunakan sebagai sampel, bila dinilai responden yang ditemui sesuai sebagai sumber data (Sugiyono 2011). Kelas umur yang digunakan adalah muda, dewasa muda, dewasa tua, dan tua. Kelas umur dibedakan menjadi empat yaitu kelas 
umur muda (13-19 tahun), kelas umur dewasa muda (20-24 tahun), kelas umur dewasa tua (25-55 tahun), dan kelas umur tua (>55 tahun) (Wibowo 1987).

\section{Analisis Data}

\section{Suhu dan Kelembapan RTH}

Suhu adalah suatu ukuran tingkat panas suatu benda (Fadholi 2013) dalam hal ini pengukuran suhu dilakukan pada ketinggian $1.5 \mathrm{~m}$ dari permukaan tanah. Selanjutnya data suhu dan kelembapan hasil pengukuran diolah untuk mendapatkan suhu rata-rata harian dan kelembapan rata-rata harian denganrumus menurut Handoko et al. (1994) yaitu sebagai berikut :

$$
\operatorname{Tr}=\frac{(2 \mathrm{Tpagi}+\mathrm{T} \text { siang }+\mathrm{T} \text { sore })}{4} \quad \mathrm{RHr}=\frac{(2 \mathrm{RHpagi}+\mathrm{RH} \text { siang }+ \text { RHsore })}{4}
$$

Keterangan :

$\mathrm{Tr} \quad$ =rata-rata suhu udara harian $\left({ }^{\circ} \mathrm{C}\right)$

$\mathrm{T}=$ suhu bola kering $\left({ }^{\circ} \mathrm{C}\right)$

$\mathrm{RHr}=$ rata-rata kelembapan udara harian $(\%)$

$\mathrm{RH}$ = kelembapan udara (\%)

Kelembapan udara adalah banyaknya uap air yang terkandung dalam udara atau atmosfer (Fadholi 2013). Kelembapan yang didapatkan dari penelitian ini adalah kelembapan relatif. Kelembapan relatif merupakan perbandingan antara kelembapan aktual dengan kapasitas udara untuk menampung uap air (Handoko 1994). Penentuan kelembapan relatif menggunakan data suhu thermometer bola kering dan suhu bola basah yang selanjutnya data suhu tersebut diolah menggunakan rumus dari Abbott et al .(1985):

$$
U=\frac{100\left[\exp \left[1.8096+\left(\frac{17.2694 T w}{237.3+T w}\right)\right]-7.866 \times 10^{-4} P(T-T w)\left(1+\frac{T w}{610}\right)\right]}{\exp \left[1.8096+\left(\frac{17.2694 T}{237.3+T}\right)\right]}
$$

Keterangan :

$\mathrm{U}=$ Kelembapan $(\%)$

$\mathrm{T}=$ Suhu Bola Kering $\left({ }^{0} \mathrm{C}\right)$

$\mathrm{T}_{\mathrm{w}}=$ Suhu Bola Basah $\left({ }^{0} \mathrm{C}\right)$

$\mathrm{P}=$ Tingkat Tekanan Berdasarkan Ketinggian $(\mathrm{hPa})$ mengacu pada Tabel 2

Tabel 2 Tekanan berdasarkan ketinggian

\begin{tabular}{lccccc}
\hline Ketinggian (m) & $0-250$ & $251-500$ & $501-750$ & $1001-1250$ & $1251-1500$ \\
\hline Tekanan (hpa) & 998.3 & 969.0 & 940.4 & 912.5 & 885.2 \\
\hline
\end{tabular}

\section{Nilai Kenyamanan Termal}

Kenyamanan termal merupakan suatu kondisi pikiran yang mengekspresikan kepuasan dengan lingkungan termal (Nugroho et al. 2007). Hasil pengukuran suhu dan kelembapan udara kemudian digunakan untuk dapat menghitung nilai kenyamanan dengan rumus menurut Nieuwolt dan Mc gregor (1998). 


$$
\mathrm{THI}=0,8 \mathrm{~T}+(\mathrm{RH} \times \mathrm{T}) / 500
$$

Keterangan :

THI = Temperatur Humidity Index $\left({ }^{0} \mathrm{C}\right)$

$\mathrm{T} \quad=$ suhu udara $\left({ }^{\circ} \mathrm{C}\right.$

$\mathrm{RH}=$ kelembapan relatif $(\%)$

Hasil perhitungan menggunakan rumus tersebut selanjutnya ditentukan kriteria tingkat kenyamanan yang dirasakan oleh masyarakat .

Tabel 3 Kriteria tingkat kenyamanan

\begin{tabular}{llll} 
No & Kriteria & THI $\left({ }^{\circ} \mathrm{C}\right)$ \\
\hline 1 & Nyaman & $21-24$ \\
2 & Cukup nyaman & $25-27$ \\
3 & Tidak nyaman & $>27$ \\
\hline
\end{tabular}

Sumber : Emmanuel (2005)

\section{Leaf Area Index (LAI)}

Leaf Area Index (LAI) menjadi parameter penting dalam arsitektur kanopi pohon. LAI didefinisikan sebagai ukuran luas sisi suatu permukaan daun persatuan luas tanahnya (Watson 1947 dalam Danner et al. 2015). Hasil pengambilan foto LAI dianalisis menggunakan software hemiview 2.1. Data diolah dengan metode threshold method (ambang batas), penentuannya dilakukan secara manual oleh peneliti dengan menaikkan atau menurunkan taraf nilai ambang batas sampai ditemukan kecocokan antara citra hasil klasifikasi dengan eitra asli yang diperoleh, sehingga didapatakan batas yang jelas antara bagian yang tertutup kanopi dengan bagian yang terbuka (Djumhaer 2003).

\section{Kerapatan}

Hasil analisis vegetasi untuk tingkat pohon dihitung kerapatannya dengan menggunakan rumus :

$$
\text { Kerapatan seluruh pohon per hektar }=\frac{\sum \text { kerapatan jenis pohon }}{\left(10000 \mathrm{~m}^{2}\right)}
$$

\section{Hubungan Antara Penambahan Jarak dengan Suhu, Kelembapan, dan Tingkat Kenyamanan}

Untuk mengetahui hubungan antara penambahan jarak dengan suhu, kelembapan, dan tingkat kenyamanaan dilakukan analisis regresi linear. Analisis regresi linear mengacu pada Sugiyono (2011) dengan persamaan :

Keterangan:

$$
Y i=\alpha+\beta X i
$$

Yi $=$ Peubah tak bebas (suhu, kelembapan)

$\mathrm{Xi}=$ Peubah bebas (jarak dari titik pusat $\mathrm{RTH}$ )

$\alpha \quad=$ Intersep

$\bar{\beta}=$ Kemiringan 


\section{Analisis Hasil Wawancara}

Hasil wawancara dengan 30 responden dianalisis secara deskriptif. Analisis secara deskriptif adalah dengan cara mendeskripsikan atau menggambarkan data yang didapatkan dari hasil penelitian. Hasil analisis data secara deskriptif bertujuan untuk menggambarkan secara sistematis terkait hubungan parameter yang teliti dengan cara mengumpulkan data, mengolah, menganalisis dan menampilkan datanya. Data hasil wawancara yang telah dianalisis secara deskriptif kemudian disajikan dalam bentuk grafik.

\section{HASIL DAN PEMBAHASAN}

\section{Kondisi Umum}

Menurut Informasi Kinerja Pengelolaan Lingkungan Hidup Daerah (IKHLD) Tahun 2016 Kota Surabaya menjadi kota terbesar kedua di Indonesia setelahJakarta yang terletak diantara $07^{\circ} 12^{\prime}-07^{\circ} 21^{\prime}$ Lintang Selatan dan $112^{\circ} 36^{\prime}$ $112^{0} 54^{\prime}$ Bujur Timur. Batas-batas wilayah kota Surabaya adalah sebelah utara dan timur berbatasan langsung dengan Selat Madura, sebelah selatan berbatasan dengan Kabupaten Sidoarjo, dan sebelah barat berbatasan dengan Kabupaten Gresik. Temperatur rata-rata Kota Surabaya adalah $29{ }^{\circ} \mathrm{C}$ dengan kelembapan relatif sebesar $77 \%$. Tekanan udara rata-rata adalah 1010.7 milibar, kecepatan angin rata-rata perjam mencapai $12-23 \mathrm{~km}$ dan curah hujan bulanan rata-rata antara 120-190 mm. Jenis tanah yang terdapat di Kota Surabaya terdiri atas jenis tanah alluvial dan grumosol, tanah alluvial terdiri atas 3 karakteristik yaitu alluvial hidromorf, alluvial kelabu tua dan alluvial kelabu. Kota Surabaya merupakan kota pantai, dimana dataran rendahnya berada pada ketinggian 3-6 m diatas permukaan laut, dan daerah berbukitnya berada di bagian selatan Kota Surabaya dengan ketinggian 20-30 m diatas permukaan laut (BPS Kota Surabaya 2016).

Luas wilayah Kota Surabaya adalah sebesar 33451 ha dengan jumlah penduduk sampai tahun 2016 mencapai 3016653 jiwa (IKPLHD Kota Surabaya 2016). Berdasarkan posisi geografis Kota Surabaya merupakan pemukiman pantai yang berpotensi menjadi tempat persinggahan dan pemukiman bagi orang pendatang. Pendatang tersebut tidak hanya berasal dari Indonesia tetapi juga etnis luar seperti Melayu, China, Arab, India, dan Eropa yang hidup bersama dan membaur dengan penduduk asli sehingga membentuk kemajemukan budaya yang menjadi ciri khas Kota Surabaya. Kota Surabaya mengalami perkembangan pesat pada sektor pendidikan dan perdagangan, industri utamanya adalah pembuatan kapal, alat berat, pengolahan makanan, agrikultur, elektronik, perabot rumah tangga serta kerajinan tangan (Profil Kota Surabaya 2016).

Kota Surabaya adalah salah satu kota di Indonesia yang saat ini gencar dalam pengembangan dan pengelolaan RTH, dalam mewujudkan kota dengan lingkungan bersih Kota Surabaya melibatkan berbagai elemen masyarakat untuk terlibat dalam pengelolaannya. Keberadaaan RTH tersebut menjadikan Surabaya terlihat lebih hijau. Berdasarkan Perda Kota Surabaya No 7 Tahun 2002 tentang Pengelolaan RTH menyatakan bahwa pengelolaan Ruang Terbuka Hijau dilaksanakan secara terpadu oleh instansi pemerintah daerah, masyarakat dan pelaku pembangunan lainnya sesuai dengan bidang tugas dan tanggung jawab 
masing-masing. Perda tersebut menjelaskan bahwa setiap orang memiliki tanggung jawab untuk menjaga RTH agar tetap terjaga keasriannya dan tidak merusaknya.

RTRW Kota Surabaya No 4 Tahun 2012 menyebutkan bahwa ruang terbuka hijau meliputi RTH publik dan RTH privat dengan luas sebesar $30 \%$ dari luas wilayah kota. RTH publik diadakan paling sedikit $20 \%$ dari luas wilayah kota yang meliputi, makam, lapangan, taman, jalur hijau, hutan kota, kawasan penyangga, sempadan waduk/boozem, sempadan saluran dan sungai, dan sempadan pantai. Upaya yang dilakukan oleh Pemerintah Kota Surabaya dalam pengelolaan RTH publik adalah melindungi dan tidak mengalih fungsikan RTH, mengembangkan kegiatan olahraga dan pariwisata dan fungsi RTH tertentu, meningkatkan fungsi ekologi pada setiap fungsi ruang terbuka hijau dan menata dan mengatur setiap fungsi RTH.

Tahun 2017 Kota Surabaya telah memiliki 93 unit taman kota yang tersebar di seluruh wilayah perkotaan, diantaranya : Taman Flora, Kebun Bibit Wonorejo, dan Hutan Kota Balas Klumprik. Hasil wawancara dengan pihak pengelola Taman Flora menyatakan bahwa awal keberadaannya Taman Flora bernama kebun bibit, yang berdiri pada tahun 1990 atas ide dari pemerintah kota sebagai tempat pengembangan pembibitan dan peremajaan tanaman, selain berfungsi sebagai hutan kota juga berfungsi sebagai area rekreasi bagi masyarakat kota dengan luasan 2.4 ha. Pada Agustus 2007 kebun bibit diresmikan dan berganti nama menjadi Taman Flora Taman Flora dikelilingi oleh jalan raya, perumahan, dan komplek pertokaan.

Kebun Bibit Wonorejo salah satu RTH yang ada sejak tahun 1990 yang memiliki luasan kurang lebih 5 ha terletak di jalan Kendalsari Wonorejo. Namun, sebelum menjadi kebun bibit area tersebut merupakan tempat pembuangan sampah, lalu dikembangkan menjadi tempat pembibitan dan pembudidayaan berbagai tanaman untuk menyokong dan mendistribusikan kebutuhan taman kota serta penghijau kota sekaligus (Yudi, staf Kebun Bibit Wonorejo, 17 Mei 2018, komunikasi pribadi).

Selain Taman Flora dan Kebun Bibit Wonorejo, Kota Surabaya juga memiliki Hutan Kota yang terletak di Jalan Raya Balas Klumprik sehingga diberi nama Hutan Kota Balas Klumprik. Hutan kota terbentuk pada tahun 2008 yang merupakan bekas lahan sawah milik pemerintah yang dialih fungsikan menjadi hutan kota untuk menjaga kelestarian dan keseimbangan ekosistem perkotaan yang meliputi unsur lingkungan, sosial, dan budaya. Hutan Kota Balas Klumprik berada dibawah pengelolaan Dinas Ketahanan Pangan dan Pertanian Kota Surabaya. Hutan Kota Balas Klumprik memiliki luas 4.3 ha, yang dikelilingi oleh kompleks perumahan dan gedung kelurahan. Terdapat danau buatan didalam kawasan dan sentra kuliner, namun belum semua tanaman di dalam hutan kota tumbuhan besar sehinngga beberapa titik di dalam hutan kota masih terlihat kosong karena tanaman yang masih dalam tahap pancang (Dwi, staf Hutan Kota Balas Klumprik, 30 April 2018, komunikasi pribadi). 


\section{Perbedaan Suhu dan Kelembapan di Dalam dan di Luar Ruang Terbuka Hijau}

\section{Kondisi Suhu di Dalam dan di Luar Ruang Terbuka Hijau}

Keberadaan RTH di perkotaan dinilai penting dalam sebuah ekosistem perkotaan terutama dalam penurunan suhu kota, penyedia udara bersih dan mengurangi pancaran radiasi sinar matahari agar tidak sampai ke permukaan. Menurut Gomez et al.(2004) kawasan hijau di perkotaan berperan untuk memengaruhi beberapa unsur iklim mikro agar lebih baik serta melemahkan atau mengurangi efek negatif (peningkatan suhu udara) di wilayah tersebut. Hasil pengukuran suhu dilakukan uji regresi linear sederhana antara jarak dari pusat ke pinggir hingga ke luar RTH dengan suhu yang diperoleh, hasil regresi linear sederhana disajikan pada Tabel 4.

Tabel 4 Regresi linear sederhana jarak dengan suhu

\begin{tabular}{lcc}
\hline \multicolumn{1}{c}{ Lokasi Penelitian } & Persamaan Regresi & Rsquare \\
\hline Taman Flora & $\mathrm{Y}=30.00+0.01 \mathrm{X}$ & 0.882 \\
Kebun Bibit Wonorejo & $\mathrm{Y}=29.64+0.02 \mathrm{X}$ & 0.717 \\
Hutan Kota Balas Klumprik & $\mathrm{Y}=28.31+0.01 \mathrm{X}$ & 0.564 \\
\hline
\end{tabular}

Keterangan : $\mathrm{Y}=\mathrm{Suhu}$; $\mathrm{X}=\mathrm{J}$ Jarak

Hasil regeresi linear sederhana didapatkan bahwa ke tiga RTH memiliki Rsquare > 0,5 yang berarti signifikan. Menurut Walpole (1982) hubungan kedua parameter dikatakan kuat apabila Rsquare $>0.5$. Terdapat hubungan linear positif antara $\mathrm{X}$ dan $\mathrm{Y}$ dimana setiap terjadi penambahan jarak terjadi kenaikan suhu (Gambar 7). Terjadi perubahan suhu ketika dilakukan pengukuran di luar ruang terbuka hijau, dimana semakin menjauhi dari area bervegetasi suhu semakin tinggi. Perubahan suhu dari dalam hingga keluar RTH disebabkan tidak adanya vegetasi diluar RTH dan terdapatnya pengeras jalan seperti aspal. Menurut Saputro (2010) area terbuka terkena radiasi matahari secara langsung, dimana radiasi matahari langsung akan memanaskan permukaan perkerasan dan selanjutnya memanaskan suhu udara diatasnya.

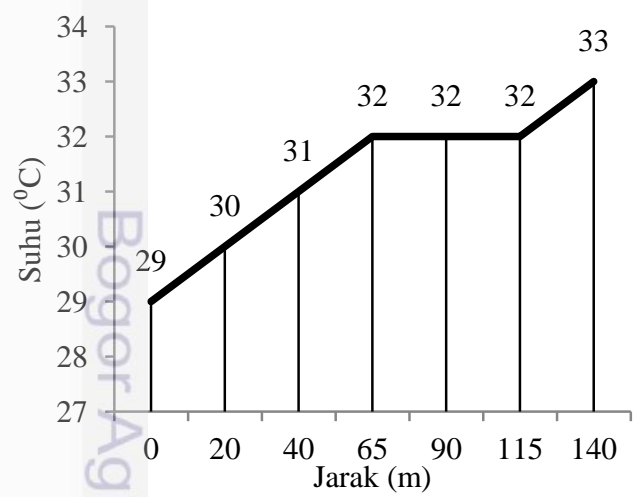

(a)

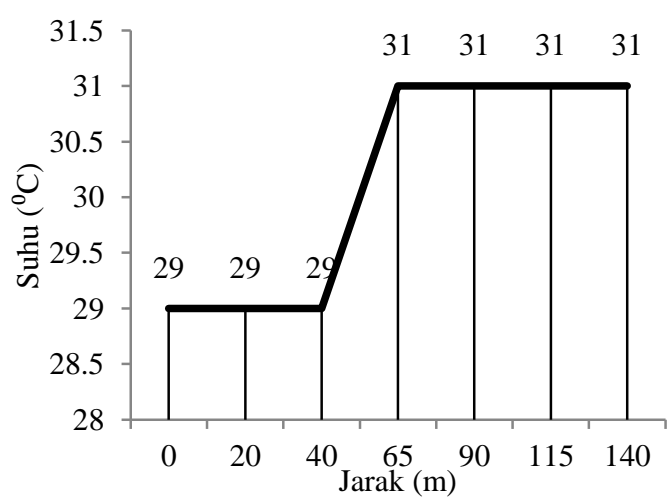

(b) 


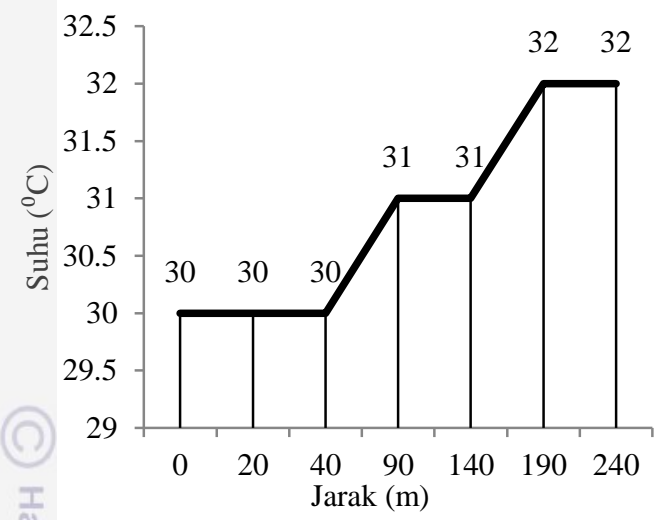

(c)

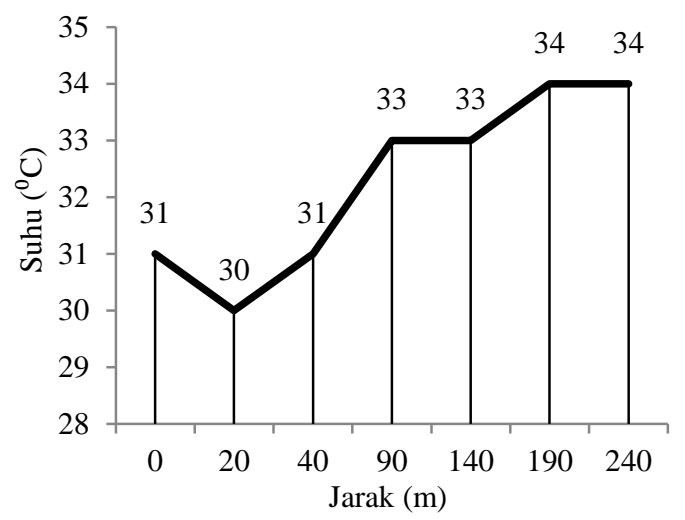

(d)

Keterangan : Jarak $0 \mathrm{~m}-40 \mathrm{~m}=$ area dalam RTH; $65 \mathrm{~m}-140 \mathrm{~m} / 90 \mathrm{~m}-240 \mathrm{~m}=$ area luar RTH

Gambar 7 (a) Perubahan suhu pada setiap jarak Taman Flora Transek 1

(b) Perubahan suhu pada setiap jarak Taman Flora Transek 2

(c) Perubahan suhu pada setiap jarak Taman Flora Transek 3

(d) Perubahan suhu pada setiap jarak Taman Flora Transek 4

Transek 1 dan 2 Taman Flora merupakan area bervegetasi dengan tajuk pohon yang lebar dan menutupi sebagian besar lokasi transek 1 dan 2. Sementara itu transek 3 dan 4 merupakan area Taman Flora yang bervegetasi namun tidak rapat dan kanopi pohonnya tidak menutupi seluruh area transek 3 dan 4 sehingga cahaya matahari dapat masuk ke lantai Taman Flora. Transek 1 dan 2 yang memiliki tutupan tajuk lebih lebar dan saling menyambung antar tajuk (Lampiran 6) dibandingkan transek 3 dan 4 menjadikan suhu dibawah kanopi pohonnya lebih rendah begitu juga ketika keluar dari RTH suhu cenderung lebih tinggi perubahnnya di transek 3 dan 4. Berdasarkan hasil penelitian Hidayat (2010) menemukan bahwa terdapat perbedaan suhu udara yang terukur dibawah kanopi (pohon) sebesar $2.9{ }^{\circ} \mathrm{C}-7.4{ }^{\circ} \mathrm{C}$ dibandingkan suhu udara tanpa adanya kanopi berupa pohon (non-vegetasi).

Area bervegetasi Taman Flora menunjukkan suhu udara yang lebih rendah jika dibandingkan dengan suhu di luar Taman Flora yaitu sebesar $29{ }^{\circ} \mathrm{C}$. Terjadi kenaikan suhu sebesar $31{ }^{\circ} \mathrm{C}-34{ }^{\circ} \mathrm{C}$ disebabkan area luar Taman Flora tidak terhalang tajuk pohon sehingga cahaya matahari langsung mengenai lantai luar Taman Flora yang berupa pengeras jalan. Kondisi tersebut menyebabkan suhu udara terus mengalami peningkatan menjauhi Taman Flora. Hasil penelitian Saputro (2010) menunjukkan bahwa peningkatan suhu udara pada area ternaungi lebih rendah sekitar $0.33-0.84{ }^{\circ} \mathrm{C}$ karena kemampuan tajuk pohon yang efektif dalam penyerapan panas dan mengurangi pemantulan. Area lantai Taman Flora sebagian besar tertutupi aspal dan konblok yang menyebabkan sinar matahari langsung mengenai lantai Taman Flora yang tidak tertutupi kanopi pohon sehingga suhu di dalam RTH ada yang tinggi seperti di luar Taman Flora. Perubahan suhu dari luar hingga dalam Taman Flora terlihat pada Gambar 8 dimana semakin menjauhi area Taman Flora warna peta semakin merah yang berarti suhu terus mengalami peningkatan dan semakin berwarna hijau suhu semakin turun. 


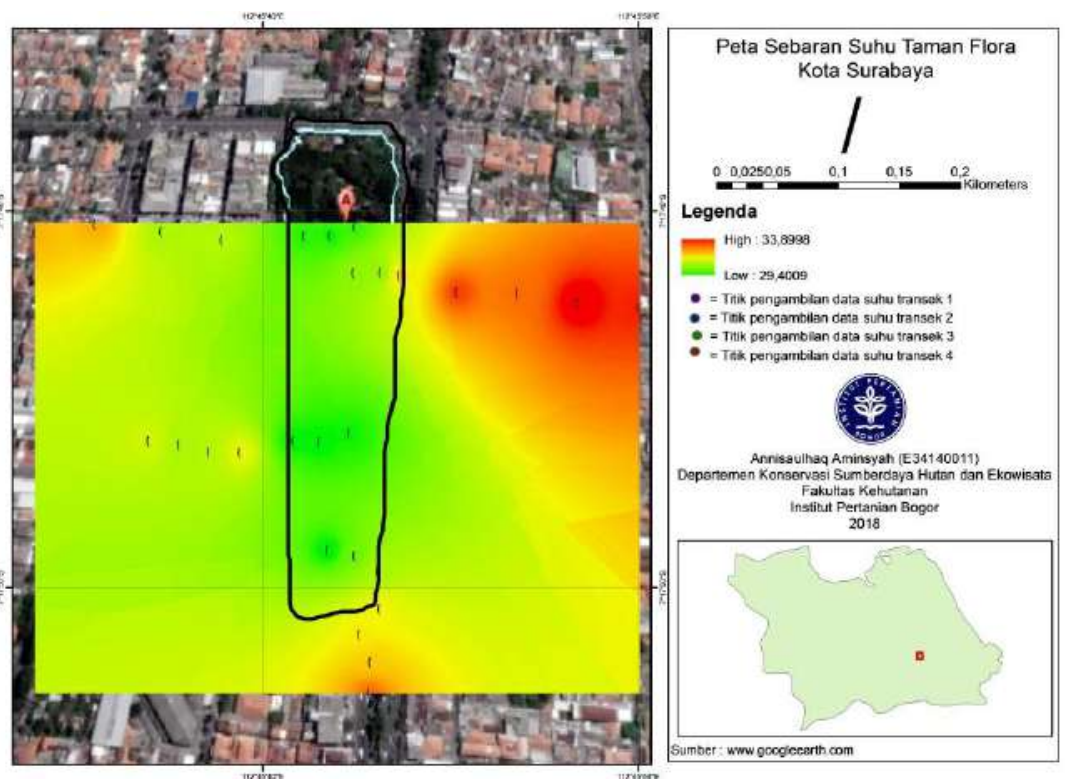

Gambar 8 Peta perubahan suhu Taman Flora

Grafik perubahan suhu pada Kebun Bibit Wonorejo menunjukkan bahwa semakin dekat dengan lokasi RTH maka suhu semakin turun (Gambar 9). Berdasarkan grafik terlihat bahwa suhu di dalam RTH ada yang mencapai $31{ }^{\circ} \mathrm{C}$ hal ini disebabkan karena tidak semua titik pengambilan suhu didalam RTH berada dibawah naungan tajuk pohon. Perubahan suhu pada setiap jarak Kebun Bibit Wonorejo transek 1 dan 2 serta transek 3 dan 4 terlihat bahwa semakin menjauhi area RTH terjadi peningkatan suhu. Transek 1 dan 2 Kebun Bibit Wonorejo tidak sepenuhnya tertutupi oleh tajuk pohon (Lampiran 6). Lantai Kebun Bibit Wonorejo ditutupi oleh pengeras jalan berupa aspal dan konblok sehingga cahaya matahari langsung masuk ke area dalam Kebun Bibit Wonorejo tanpa terhalangi oleh kanopi pohon sehingga mengalami peningkatan suhu di dalam RTH. Hasil penelitian Saputro (2010) menemukan material konblok pada area terbuka yang berwarna gelap (abu-abu tua, merah kusam) memiliki albedo yang sedikit lebih besar (25-35\%) yang memiliki peningkatan suhu udara lebih besar daripada rumput (10-15\%) dengan tekstur permukaanya lebih kasar dan berwarna gelap (hijau tua).

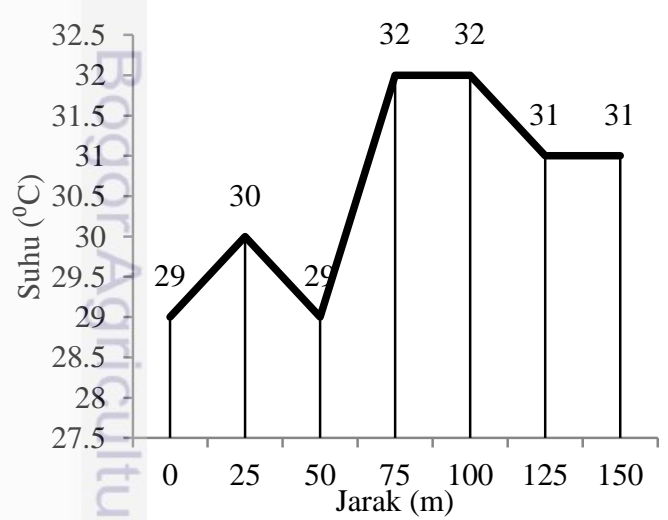

(a)

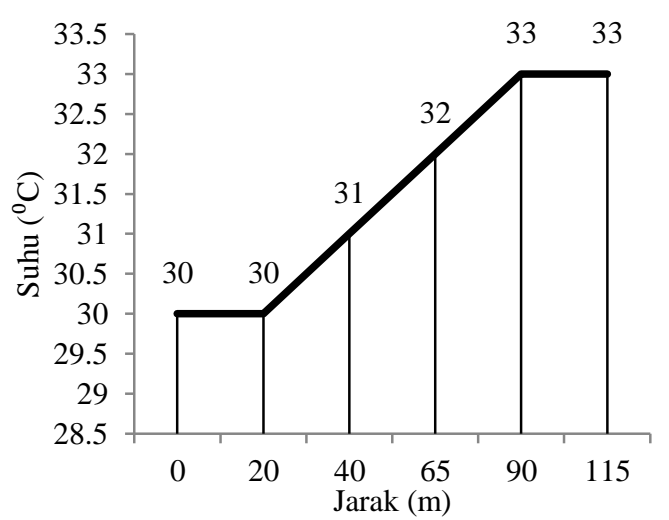

(b) 


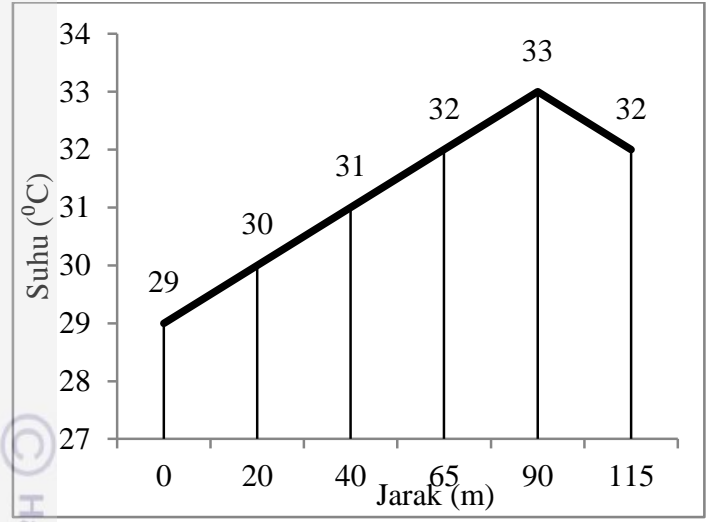

(c)

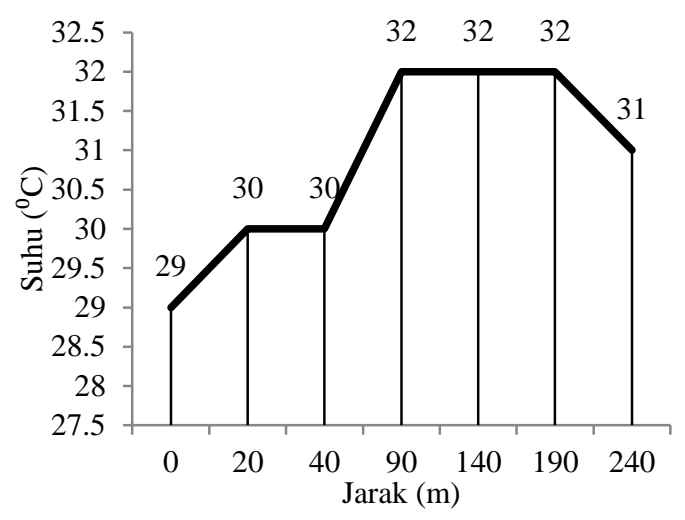

(d)

Keterangan : $0 \mathrm{~m}-40 \mathrm{~m} / 0 \mathrm{~m}-50 \mathrm{~m}=$ area dalam $\mathrm{RTH}$;

$75 \mathrm{~m}-150 \mathrm{~m} / 65 \mathrm{~m}-115 \mathrm{~m} / 90 \mathrm{~m}-240 \mathrm{~m}=$ area luar RTH

Gambar 9 (a) Perubahan suhu pada setiap jarak Kebun Bibit Wonorejo transek 1

(b) Perubahan suhu pada setiap jarak Kebun Bibit Wonorejo transek 2

(c) Perubahan suhu pada setiap jarak Kebun Bibit Wonorejo transek 3

(d) Perubahan suhu pada setiap jarak Kebun Bibit Wonorejo transek 4

Area bervegetasi pada Kebun Bibit Wonorejo di dominasi oleh pohon Trembesi (Samanea saman), Jati (Tectona grandis), Angsana (Pterocarpus indicus) dan Mahoni (Swietenia mahagoni). Kawasan dalam RTH terdapat arena bermain anak dan jogging track dimana arena bermain anak dan jogging track tersebut tertutupi oleh material aspal dan konblok dan tidak tertutupi kanopi pohon seluruhnya sehingga cahaya matahari dapat masuk mengenai lantai Kebun Bibit Wonorejo. Semakin menjauhi area Kebun Bibit Wonorejo suhu udara semakin meningkat seperti terlihat pada Gambar 10 area yang berwarna hijau merupakan Kebun Bibit Wonorejo yang suhunya turun dibandingkan suhu di luar Kebun Bibit Wonorejo berwarna merah yang menandakan kenaikan suhu yang tinggi. Kenaikan suhu di luar Kebun Bibit Wonorejo disebabkan tidak adanya vegetasi pohon yang berakibat pada sinar matahari langsung mengenai pengeras jalan dan menaikan suhu udara.

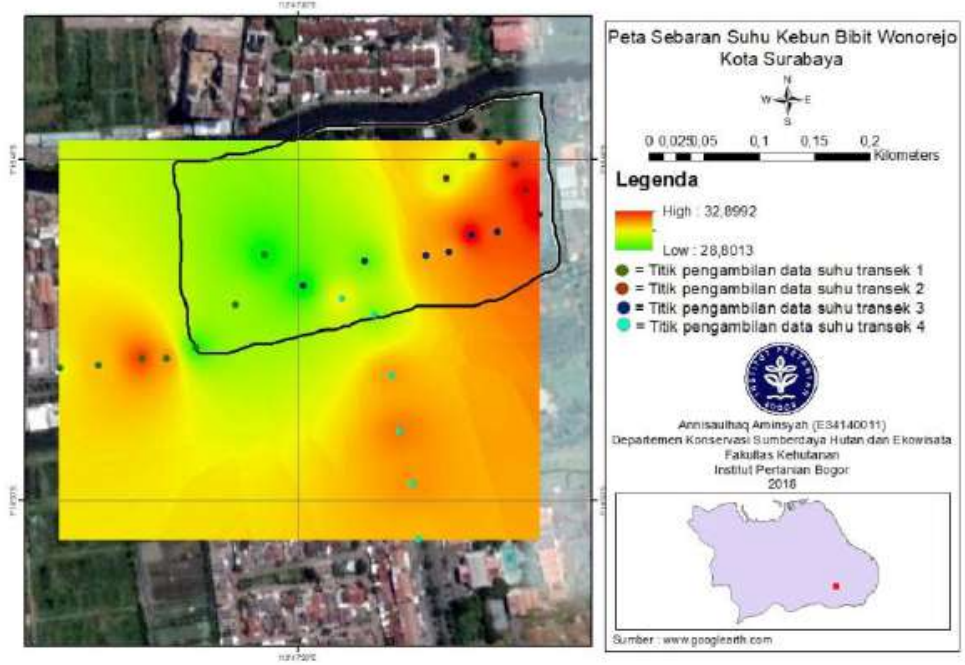

Gambar 10 Peta perubahan suhu Kebun Bibit Wonorejo 
Grafik suhu Hutan Kota Balas Klumprik pada transek 1 dan 4 serta transek 2 dan 3 terlihat pada Gambar 11, dimana menunjukkan bahwa suhu semakin turun ketika mendekati pusat RTH. Kondisi RTH yang memiliki vegetasi pohon yang rapat menjadikan suhu udara di dalam RTH menjadi lebih rendah dibandingkan di luar RTH. Menurut Shahidan et al. (2010) transmisi panas radiasi yang semakin kecil akan memberikan efek dingin terhadap suhu tanah di bawah kanopi. Kerapatan vegetasi di transek 1 dan 4 maupun 2 dan 3 dikatakan tinggi dengan kanopi pohon yang hampir menutupi semua lantai RTH, sehingga cahaya matahari tidak langsung mengenai lantai hutan yang berakibat pada penurunan suhu di bawah kanopi pohon dibandingkan dengan di luar RTH. Suhu udara semakin tinggi apabila semakin menjauh dari ruang terbuka hijau, hal ini disebabkan tidak adanya vegetasi yang menahan radiasi matahari sehingga suhu udara meningkat. Lokasi RTH penelitian yang dikelilingi oleh pemukiman, pertokōan, dan jalan raya menyebabkan radiasi matahari diserap langsung sehingga suhu meningkat. Menurut Sulistyantara dan Yuritaka (1995) gedunggedung dan perkerasan seperti jalan aspal memberikan kontribusi besar terhadap suhu permukaan yang mencapai $56{ }^{\circ} \mathrm{C}$, sedangkan pada kawasan hijau daerah urban menunjukkan suhu yang stabil $<35^{\circ} \mathrm{C}$.

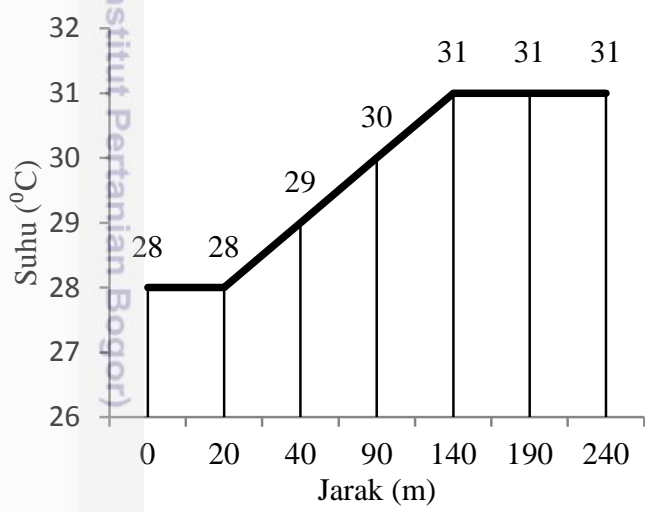

(a)

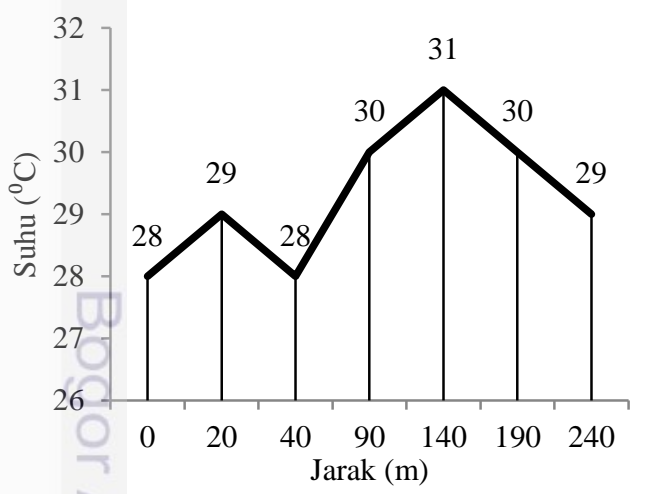

(c)

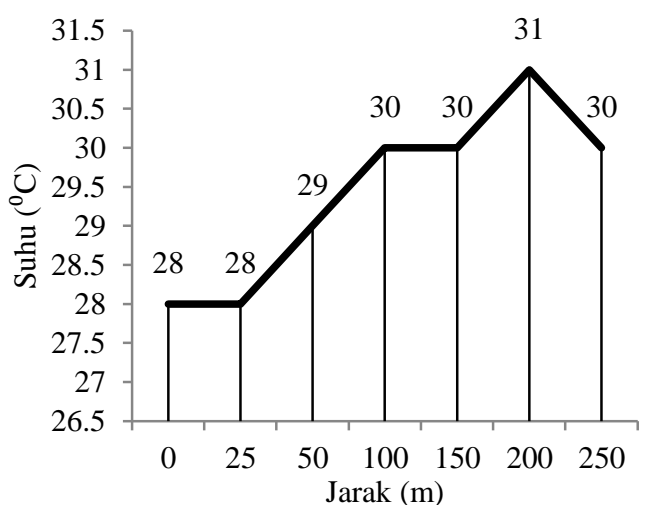

(b)

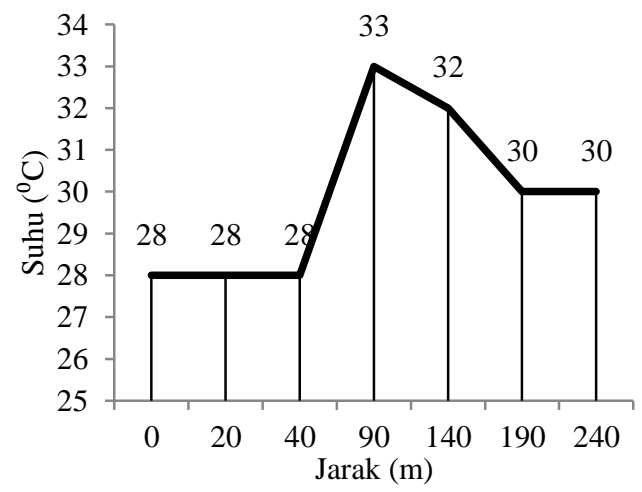

(d)

Keterangan :

$0-40 \mathrm{~m}$ dan $0-50 \mathrm{~m} \quad=$ area dalam RTH

$90-240 \mathrm{~m}$ dan $100-250 \mathrm{~m}$ = area luar RTH

Gambar 11 (a) Perubahan suhu pada setiap perubahanjarak Hutan Kota Balas Klumprik transek 1.

(b) Perubahan suhu pada setiap perubahanjarak Hutan Kota Balas Klumprik transek 2. 
(c) Perubahan suhu pada setiap perubahanjarak Hutan Kota Balas Klumprik transek 3.

(d) Perubahan suhu pada setiap perubahanjarak Hutan Kota Balas Klumprik transek 4.

Vegetasi di Hutan Kota Balas Klumprik didominasi oleh pohon Jabon (Neolamarckia cadamba), Trembesi (Samanea saman) dan Falmboyan (Delonix regia). Pohon Jabon paling banyak ditemukan disebabkan pohon tersebut telah ditanam sejak lama sebelum Hutan Kota Balas Klumprik berdiri. Terjadi peningkatakan suhu udara semakin menjauhi area RTH, sementara semakin mendekati area RTH terjadi penurunan suhu seperti yang terlihat pada Gambar 12. Menurut Dahlan (2004) suhu udara daerah berpepohonan lebih nyaman daripada daerah yang tidak ditumbuhi pohon, karena daun mempunyai kemampuan memantulkan kembali sinar infra merah sebesar 70\%, sedangkan untuk cahaya tampak dengan berbagai panjang gelombang $(380-780 \mathrm{~nm})$ hanya berkisar 6$12 \%$.

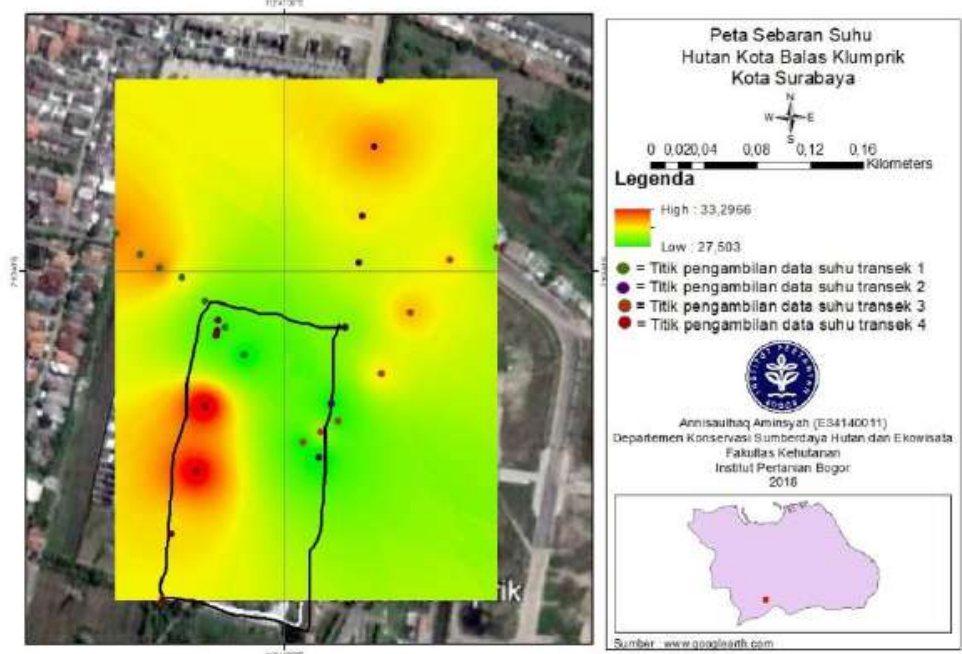

Gambar 12 Peta perubahan suhu Hutan Kota Balas Klumprik

\section{Kondisi Kelembapan di Dalam dan di Luar Ruang Terbuka Hijau}

Pengukuran terhadap kelembapan udara dilakukan bersamaan dengan mengukur suhu udara. Handoko (1995) menyatakan kelembapan relatif udara dipengaruhi oleh suhu udara dan tidak berlaku sebaliknya. Semakin meningkat suhu udara maka kelembapan udara semakin turun begitu pula dengan sebaliknya. Menurut Saputro (2010) nilai kelembapan udara relatif dipengaruhi oleh berbagai faktor diantaranya adalah tingkat ketersediaan bahan penguap, suhu udara, dan radiasi matahari. Hasil dari pengukuran kelembapan menunjukkan bahwa semakin jauh dari lokasi ruang terbuka hijau maka kelembapan semakin menurun. Persamaan regresi perubahan kelembapan udara terhadap jarak pengukuran dari titik pusat RTH seperti pada Tabel 5. 
Tabel 5 Regresi linear sederhana jarak dengan kelembapan

\begin{tabular}{llc}
\hline \multicolumn{1}{c}{ Lokasi Penelitian } & Persamaan Regresi & Rsquare \\
\hline Taman Flora & $\mathrm{Y}=82.73-0.05 \mathrm{X}$ & 0.839 \\
Kebun Bibit Wonorejo & $\mathrm{Y}=83.45-0.06 \mathrm{X}$ & 0.633 \\
Hutan Kota Balas Klumprik & $\mathrm{Y}=75.72-0.02 \mathrm{X}$ & 0.679 \\
\hline
\end{tabular}

Keterangan : Y= Kelembapan; $\mathrm{X}=$ Jarak

Hasil regresi menunjukkan bahwa adanya hubungan bernilai linear negatif antar jarak dengan perubahan kelembapan udara. Setiap penambahan jarak berakibat pada penurunan kelembapan. Terdapat hubungan yang signifikan antara kelembapan dengan jarak dimana Rsquare > 0.5. Nilai $\mathrm{R}$ pada Taman Flora sebesar 0.839, Kebun Bibit Wonorejo sebesar 0.633, dan Hutan Kota balas Klumprik sebesar 0.679. Lokasi dengan jumlah vegetasi lebih tinggi memiliki kelembapan yang lebih tinggi daripada lokasi tanpa ada naungannya. Menurut Aprihatmoko (2013) semakin sedikitnya radiasi yang diterima RTH akan memungkinkan terjadinya penurunan suhu udara dan peningkatan kelembapan relatif di sekitar sehingga dapat memperbaiki kenyamanan termal manusia. Lokasi di luar RTH yang minim akan naungan mengakibatkan kelembapan semakin kecil karena adanya tekanan uap yang besar sesuai dengan pernyatan Handoko (1995) bahwa meningkatnya defisit tekanan uap menyebabkan kelembapan udara relatif area terbuka lebih rendah dibandingkaan dengan area rumput maupun ternaungi. Berikut grafik perubahan kelembapan terhadap perubahan jarak di lokasi penelitianTaman Flora pada Gambar 13.

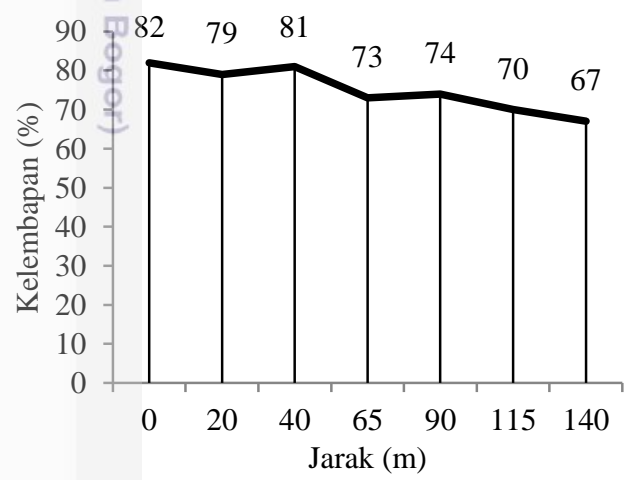

(a)

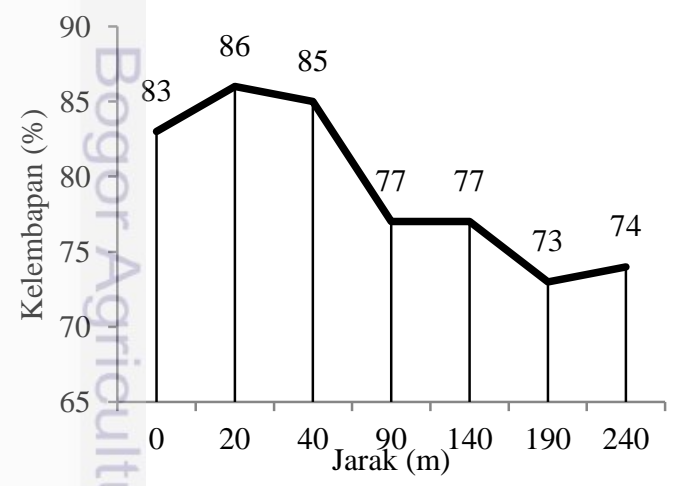

(c)

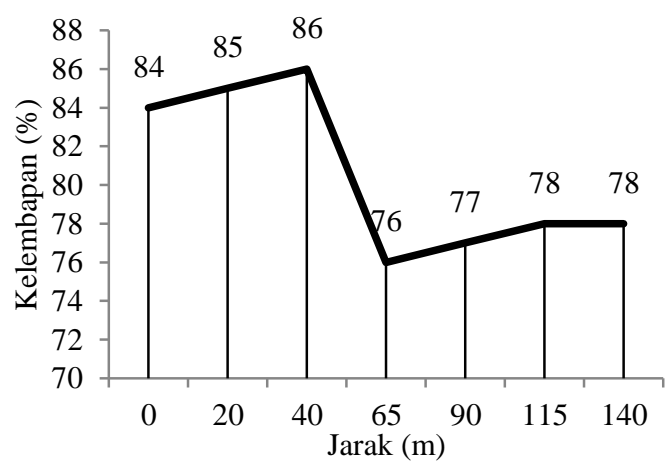

(b)

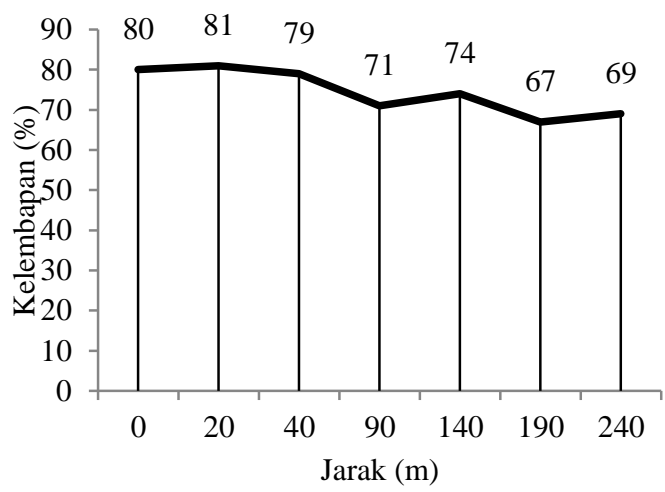

(d)

Keterangan :

$0-40 \mathrm{~m} \quad$ = area dalam RTH

$65-140 \mathrm{~m}$ dan $90-240 \mathrm{~m}=$ area luar RTH 


\section{Gambar 13 (a) Perubahan kelembapan terhadap perubahan jarak Taman Flora Transek 1 \\ (b) Perubahan kelembapan terhadap perubahan jarak Taman Flora Transek 2 \\ (c) Perubahan kelembapan terhadap perubahan jarak Taman Flora Transek 3 \\ (d) Perubahan kelembapan terhadap perubahan jarak Taman Flora Transek 4}

Pusat RTH terdapat pada 0 meter dimana kelembapan lebih tinggi dibandingkan dengan lokasi di luar RTH. Lokasi transek 1 dan 2 pada Taman Flora memiliki naungan berupa pohon dengan tajuk yang lebar, meski tajuk antar pohon tidak tumpang tindih namun menyambung antar tajuknya sehingga lantai Taman Flora dapat dinaungi. Perubahan kelembapan terhadap perubahan jarak Taman Flora transek 3 dan 4 terlihat bahwa semakin menjauhi area RTH terjadi penurunan kelembapan hingga 69\%. Hasil penelitian Aprihatmoko (2013) menjelaskan bahwa naungan dapat berfungsi untuk menghalangi radiasi matahari yang masuk ke ruang terbuka hijau sehingga radiasi matahari yang digunakan untuk pemanasan suhu udara akan semakin kecil. Suhu udara yang semakin kecil menjadikan kelembapan udara meningkat.

Keberadaan vegetasi terutama pohon di dalam RTH mampu menurunkan suhu dan meningkatkan kelembapan sehingga dapat memberikan rasa nyaman saat berada di dalam ruang terbuka hijau (RTH). Pusat Kebun Bibit Wonorejo berada pada 0 meter dimana kelembapan lebih tinggi jika dibandingkan dengan di luar RTH (Gambar 14). Transek 3 dan 4 Kebun Bibit Wonorejo berada pada lokasi dengan vegetasi yang banyak pohonnya sehingga kelembapan di dalamnya tinggi. Menurut Sanger et al. (2016), pepohonan cenderung memiliki kelembapan udara yang tinggi karena aktivitas evapotranspirasi tanaman pada gerombolan pohon dapat meningkatkan kelembapan udara di sekitarnya. Lokasi di luar Kebun Bibit Wonorejo mengalami penurunan kelembapan namun tidak terlalu besar. Penurunan kelembapan yang tidak terlalu besar ini disebabkan beberapa titik pengukuran hingga titik terjauh Kebun Bibit Wonorejo terdapat vegetasi rumput dan pancang. Grafik perubahan kelembapan terhadap perubahan jarak pada Kebun Bibit Wonorejo tersaji pada Gambar 14.

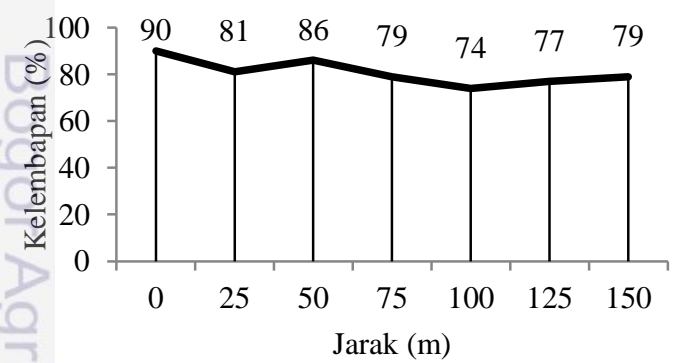

(a)

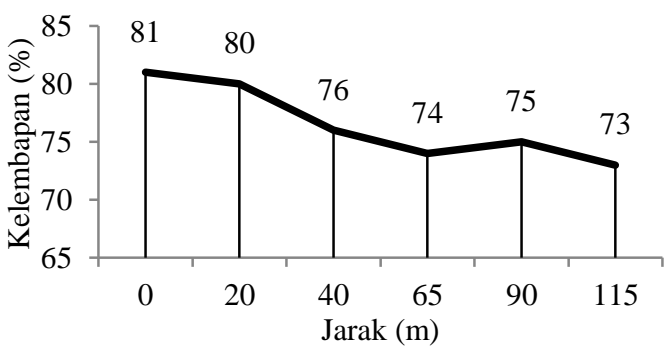

(b) 


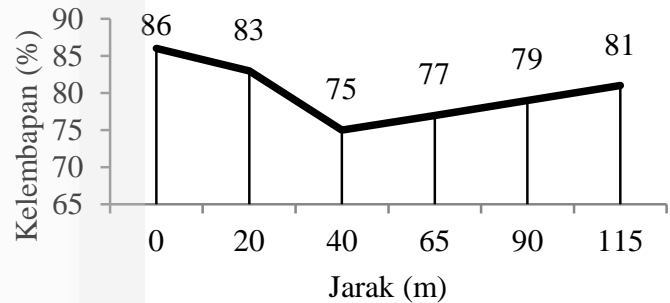

(c)

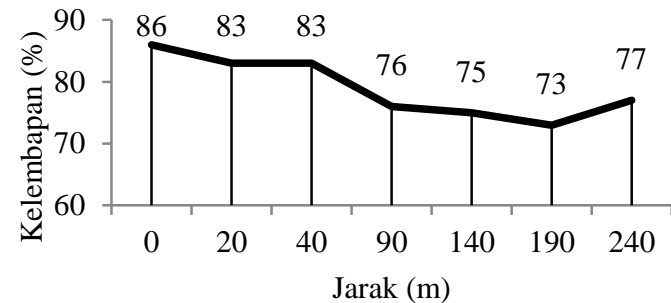

(d)

Keterangan :

$0 \mathrm{~m}-40 \mathrm{~m} / 0 \mathrm{~m}-50 \mathrm{~m}=$ area dalam RTH

$75 \mathrm{~m}-150 \mathrm{~m} / 65 \mathrm{~m}-115 \mathrm{~m} / 90 \mathrm{~m}-240 \mathrm{~m}=$ area luar RTH

Gambar 14 (a) Perubahan kelembapan terhadap perubahan jarak Kebun Bibit Wonorejo Transek 1.

(b) Perubahan kelembapan terhadap perubahan jarak Kebun BibitWonorejo Transek 2.

(c) Perubahan kelembapan terhadap perubahan jarak Kebun BibitWonorejo Transek 3.

(d) Perubahan kelembapan terhadap perubahan jarak Kebun BibitWonorejo Transek 4.

Keberadaan vegetasi sangat penting dalam peningkatakan kelembapan di sekitarnya, sehingga hal tersebut dapat memberikan efek nyaman saat berada di area bervegetasi. Pengukuran kelembapan pada Hutan Kota Balas Klumprik (Gambar 15) dilakukan pada 4 transek dimana jarak pengukuran diluar RTH nya berada pada rentang $50 \mathrm{~m}$, hal tersebut dikarenakan lokasi pengamatan suhu yang luas sehingga memungkinkan untuk melakukan pengukuran suhu hingga titik terjauh dari RTH. Area bervegetasi atau Hutan Kota Balas Klumprik pada transek 1 dan 4 terletak pada 0 meter hingga 40 meter dimana terlihat bahwa pada pusat RTH terjadi peningkatan kelembapan hingga $80 \%$ dibandingkan di luar RTH. Satu titik terluar RTH transek 4 memiliki kelembapan tinggi hal tersebut disebabkan terdapatnya beberapa vegetasi pohon di sekitar pengukuran sehingga kelembapan menjadi lebih tinggi.

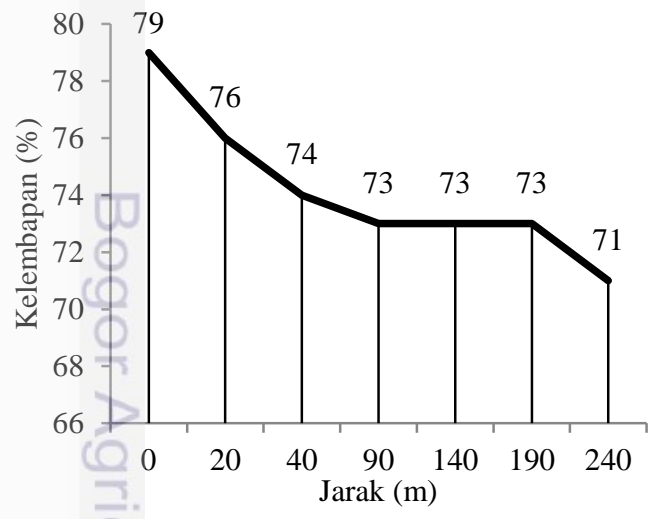

(a)

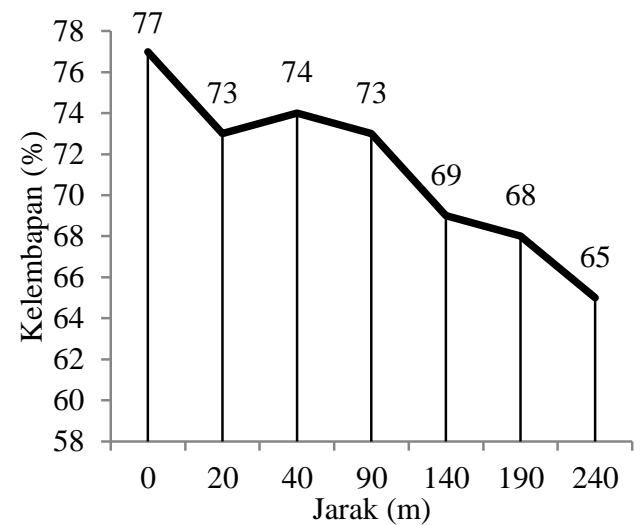

(b) 


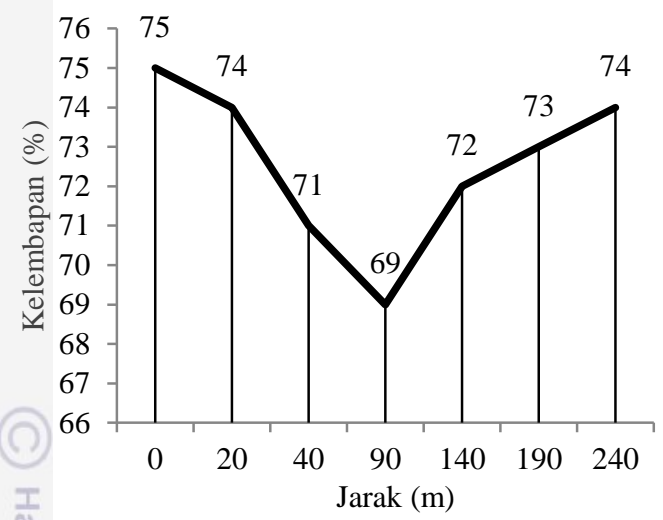

(c)

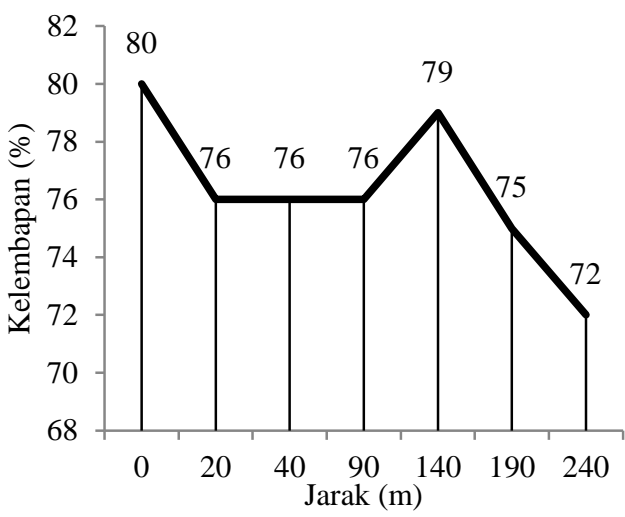

(d)

Keterangan :

$0-40 \mathrm{~m}$ dan $0-50 \mathrm{~m} \quad=$ area dalam $\mathrm{RTH}$

90 - $240 \mathrm{~m}$ dan $100-250 \mathrm{~m}=$ area luar RTH

Gambar 15 (a) Perubahan kelembapan terhadap perubahan jarak pada Hutan Kota Balas Klumprik Transekek 1.

(b) Perubahan kelembapan terhadap perubahan jarak pada Hutan Kota Balas Klumprik Transekek 2.

(c) Perubahan kelembapan terhadap perubahan jarak pada Hutan Kota Balas Klumprik Transekek 3.

(d) Perubahan kelembapan terhadap perubahan jarak pada Hutan Kota Balas Klumprik Transekek 4.

Area transek 2 dan 3 memiliki vegetasi pohon yang banyak (Lampiran 6) dengan tajuk yang lebar sehingga menutupi lantai Hutan Kota Balas Klumprik. Kurangnya radiasi yang diterima oleh lantai Hutan Kota Balas Klumprik karena terhalang tajuk pohon mengakibatkan kelembapan relatif tinggi di bawah tajuk. Hasil penelitian Sanger et al. (2016) menyebutkan pohon memiliki tajuk yang berfungsi menyebarkan sinar matahari yang masuk sehingga suhu udara di bawah naungan pohon lebih rendah bila dibandingkan dengan area vegetasi lain. Area di sekeliling Hutan Kota Balas Klumprik merupakan area perumahan dan gedung perkantoran sehingga cahaya matahari diserap langsung tanpa penghalang sehingga suhu meningkat dan kelembapan menjadi menurun. Adapun di beberapa titik terdapat kenaikan kelembapan dikarenakan lokasi pengambilan data terletak di dekat pohon ataupun rumput yang bisa menyerap radiasi sinar matahari.

\section{Pengaruh Kerapatan Vegetasi dan LAI dengan Suhu dan Kelembapan di Ruang Terbuka Hijau}

\section{Leaf Area Index (LAI) di Ruang Terbuka Hijau}

Pengukuran terhadap LAI pada lokasi penelitian dilakukan dengan membagi kawasan penelitian menjadi beberapa transek dilihat dari tajuk yang cukup rapat hingga tajuk yang rengang. Taman Flora sendiri dilakukan pengambilan data LAI sebanyak 9 plot, Kebun Bibit Wonorejo sebanyak 13 plot LAI, sedangkan untuk Hutan Kota Balas Klumprik sebanyak 6 plot LAI. Tabel 6 menunjukkan hasil pengukuran terhadap LAI di lokasi penelitian. Nilai rata-rata LAI tertinggi berada pada Taman Flora yaitu sebesar 1.597, berdasarkan klasifikasi menurut Turner et 
al. (1999) Taman Flora, Kebun Bibit Wonorejo, dan Hutan Kota Balas Klumprik termasuk dalam kategori kebun. Menurut Risdiyanto dan Setiawan (2007) indeks luas daun (LAI) adalah suatu peubah yang menunjukkan hubungan antara luas dengan luas bidang yang tertutupi. Luas yang dimaksud adalah luas tajuk pohon sedangkan luas bidang yang ditutupi merupakan lantai hutan dalam hal ini lantai ruang terbuka hijau Kota Surabaya. Menurut Rushayati (2012), Leaf Area Index (LAI) yang meningkat akan menciptakan kondisi iklim mikro khususnya suhu udara yang semakin rendah dan kelembapan yang semakin tinggi, semakin meningkatnya LAI akan menurunkan nilai tingkat kenyamanan (THI) sehingga akan meningkatkan kenyamanan.

Tabel 6 Nilai LAI ruang terbuka hijau

\begin{tabular}{lccc}
\hline \multicolumn{1}{c}{ Lokasi Penelitian } & Rata-rata LAI & Rentang LAI & Vegetasi \\
\hline Taman Flora & 1.597 & $0.876-2.945$ & Kebun \\
Kebun Bibit Wonorejo & 1.457 & $0.335-2.727$ & Kebun \\
Hutan Kota Balas Klumprik & 1.230 & $0.509-2.266$ & Kebun \\
\hline
\end{tabular}

Taman Flora memiliki nilai LAI lebih besar dibandingkan dengan dua ruang terbuka hijau lainnya. Rata-rata ketiga nilai LAI ruang terbuka hijau tidak berbeda jauh namun masih dikatakan kecil dibandingkan dengan LAI hutan alam yaitu 3.39 (Setiawan 2006). Rentang nilai LAI pada ketiga ruang terbuka hijau tergolong jauh, hal ini disebabkan karena kondisi ruang terbuka hijau yang tidak semuanya dinaungi oleh pohon beberapa bagaian dari ruang terbuka hijau hanya ditumbuhi oleh beberapa pohon saja. Nilai LAI ketiga ruang terbuka hijau semakin kecil atau sama dengan 0 maka kondisi lahan dikatakan tidak bervegetasi, Menurut Handoko et al. (2010) nilai LAI tidak ada tajuk tanaman atau nilai LAI $=0$. Menurut Setiawan (2014) nilai LAI menggambarkan luas tajuk area di dalam kawasan hutan, jika nilai LAI besar maka diasumsikan bahwa kawasan tersebut memiliki luas tajuk yang rapat.

Nilai rata-rata LAI tertinggi berada Taman Flora yaitu 1.597, tidak semua lokasi di dalam Taman Flora tertutupi tajuk pohon, dibeberapa lokasi terdapat area terbuka dan sedikit vegetasi pohonnya. Pengambilan data LAI dilakukan sebanyak 9 plot di dalam Taman Flora. Nilai LAI terendah Taman Flora sebesar 0.876 dan nilai LAI tertinggi sebesar 2.945, berikut Gambar 16 merupakan potret LAI terendah dan tertinggi Taman Flora.

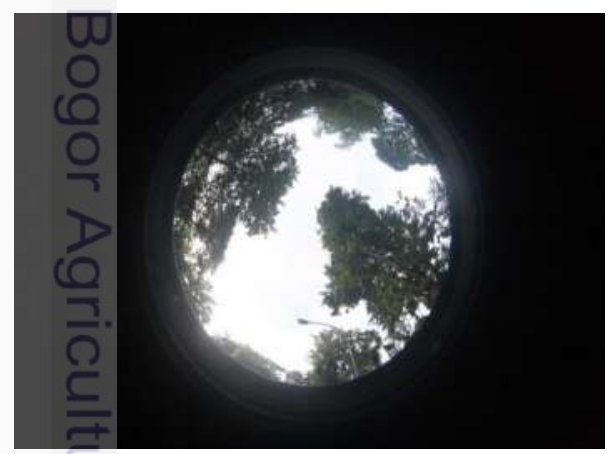

(a)

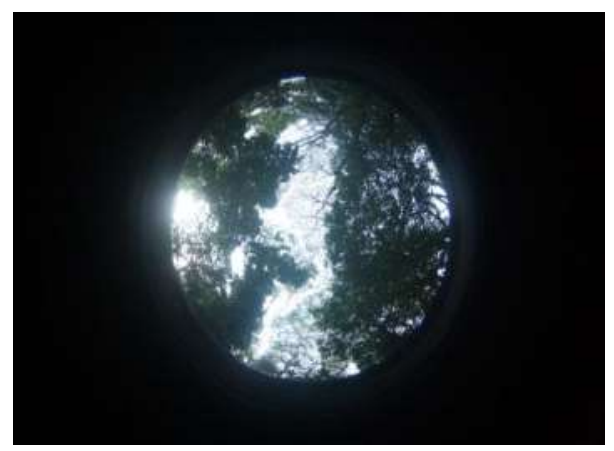

(b)

Gambar 16 (a) LAI terendah Taman Flora; (b) LAI tertinggi Taman Flora 
Nilai rata-rata LAI Kebun Bibit Wonorejo 1.457 dan berdasarkan klasifikasi Turner et al. (1999) termasuk kategori kebun. Pengambilan data LAI dilakukan sebanyak 13 plot di dalam Kebu Bibit Wonorejo. Nilai LAI terendah pada Kebun Bibit Wonorejo sebesar 0.335 dan LAI tertinggi sebesar 2.727, berikut Gamba 17 potret LAI terendah dan tertinggi Kebun Bibit Wonorejo.

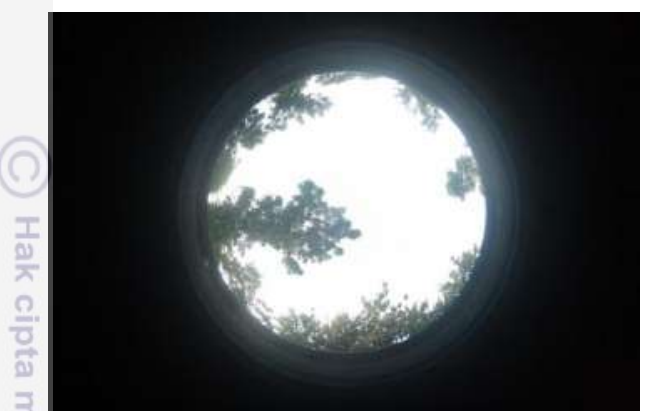

(a)

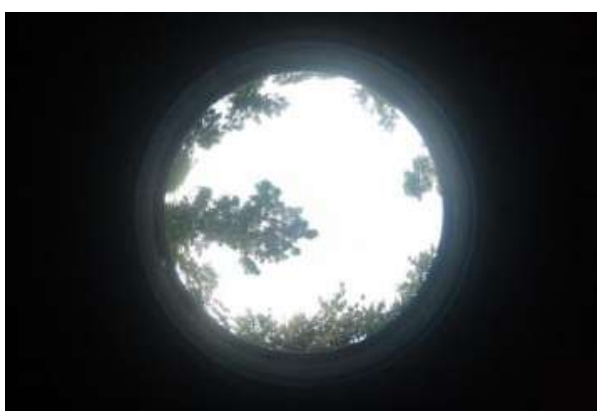

(b)

Gambar 17 (a) LAI terendah Kebun Bibit Wonorejo; (b) LAI tertinggi Kebun Bibit Wonorejo

Pengambilan LAI pada Hutan Kota Balas Klumprik dilakukan sebanyak 6 plot yang tersebar di dalam Hutan Kota Balas Klumprik. Nilai rata-rata LAI Hutan Kota Balas Klumprik sebesar 1.230, menurut Turner et al. (1999) termasuk kategori kebun. Potret LAI terendah dan tertinggi Hutan Kota Balas Klumprik terdapat pada Gambar 18, dimana nilai LAI terendah memiliki nilai sebesar 0.509 dan nilai LAI tertinggi sebesar 2.266.

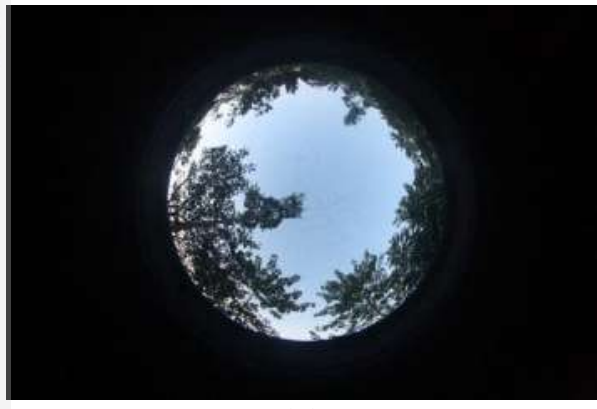

(a)

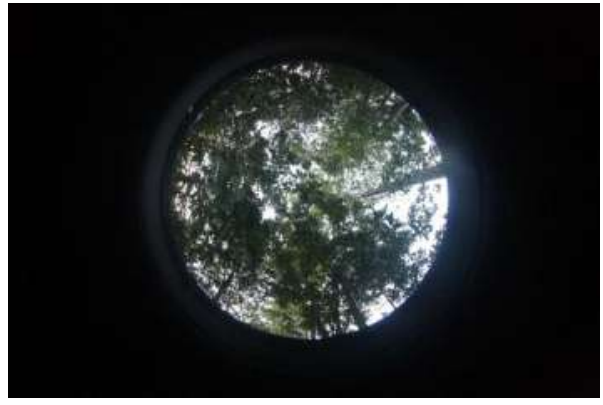

(b)

Gambar 18 (a) LAI terendah Hutan Kota Balas Klumprik; (b) LAI tertinggi Hutan Kota Balas Klumprik

Nilai LAI Taman Flora sebesar 1.857 memiliki suhu $29^{\circ} \mathrm{C}$ sedangkan nilai LAI 1.257 memiliki suhu sebesar $30^{\circ} \mathrm{C}$. Nilai LAI tertinggi pada Kebun BIbit Wonorejo sebesar 1.917 dengan suhu di lokasi plot $29^{\circ} \mathrm{C}$ dan nilai LAI 0.900 memiliki suhu $30{ }^{\circ} \mathrm{C}$. Rendahnya nilai LAI pada Kebun Bibit Wonorejo karena terdapat lokasi di dalam kawasan yang tidak tertutupi oleh tajuk pohon sehingga cahay matahari dapat masuk dan mengenai lantai kawasan Kebun Bibit Wonorejo. Nilai LAI tertinggi Hutan Kota Balas Klumprik yaitu sebesar 1.679 dengan suhu dibawah naungannya $28{ }^{\circ} \mathrm{C}$ dan LAI terendah 0.97 namun suhu di bawah tajuk pohonnya $28{ }^{\circ} \mathrm{C}$. Hubungan antara LAI dengan suhu di lokasi penelitian menunjukkan semakin besar nilai LAI maka suhu semakin kecil. Nilai LAI yang 
tinggi disebabkan luas tajuk pohon dari lokasi penelitian yang rapat sehingga menghalangi sinar matahari mengenai lantai lokasi penelitian. Menurut Handoko et al. (2010) semakin besar nilai LAI maka permukaan daun semakin luas dan daun menjadi makin rapat sehingga kemampuan tajuk tanaman untuk menutupi permukaan tanah semakin besar yang berakibat radiasi surya yang ditansmisikan dan sampai permukaan tanah semakin berkurang. Gambar 19 grafik hubungan LAI dengan suhu.

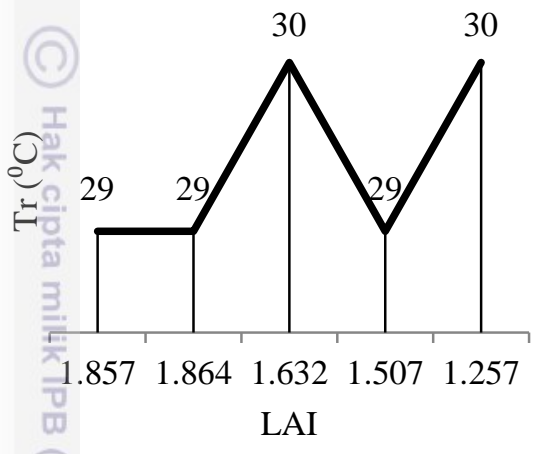

(a)

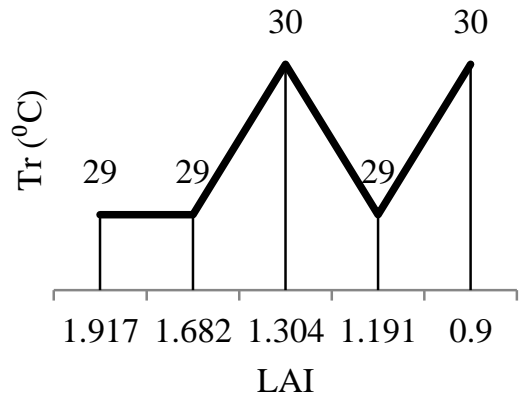

(b)

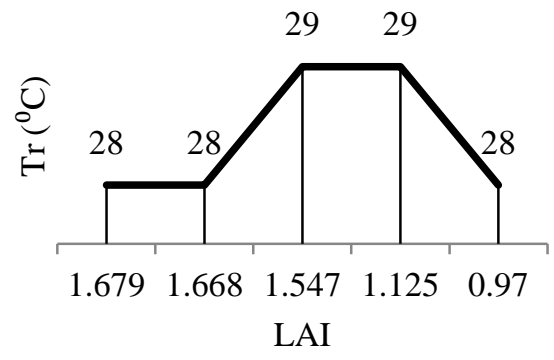

(c)

Gambar 19: (a) Hubungan LAI dengan suhu Taman Flora

(b) Hubungan LAI dengan suhu Kebun Bibit Wonorejo

(c) Hubungan LAI dengan suhu Hutan Kota Balas Klumprik

Hasil regeresi linear sederhana hubungan antara suhu dengan LAI disajikan pada Tabel 7.

Tabel 7 Regresi linear sederhana antar LAI dengan suhu

\begin{tabular}{lcc}
\hline \multicolumn{1}{c}{ Lokasi penelitian } & Persamaan Regresi & Rsquare \\
Taman Flora & $\mathrm{Y}=31.63-1.37 \mathrm{X}$ & 0.410 \\
Kebun Bibit Wonorejo & $\mathrm{Y}=30.68-0.91 \mathrm{X}$ & 0.452 \\
Hutan Kota Balas Klumprik & $\mathrm{Y}=28.80-0.28 \mathrm{X}$ & 0.029 \\
\hline
\end{tabular}

Keterangan : $\mathrm{Y}=\mathrm{Suhu} ; \mathrm{X}=\mathrm{LAI}$

Adanya hubungan yang bernilai linear negatif antara LAI dengan suhu dimana semakin bertambahnya nilai LAI maka akan semakin turun suhu udara di bawah tajuk. Namun hubungan LAI terhadap suhu tidak berpengaruh signifikan, hal tersebut dilihat pada Tabel 7 dimana nilai Rsquare $<0,5$. Dimungkinakan adanya faktor lain yang mempengaruhi suhu selain LAI. 


\section{Kerapatan Vegetasi di Ruang Terbuka Hijau}

Hasil analisis vegetasi terhadap tiga lokasi ruang terbuka hijau ditemukan 173 individu, 32 jenis dan 20 famili. Kerapatan tertinggi terdapat pada Hutan Kota Balas Klumprik yaitu 163 ind/ha. Rincian jumlah individu, jenis, famili dan kerapatan tiap ruang terbuka hijau dapat dilihat pada Tabel 8. Kerapatan vegetasi di ruang terbuka hijau memiliki peran penting dalam menurunkan suhu udara di dalam dan di sekitar ruang terbuka hijau. Semakin tinggi nilai kerapatan pohon maka akan dapat mengurangi energi radiasi matahari sehingga dapat mereduksi suhu udara di sekitarnya, dan kelembapan udara pada suatu daerah akan berbeda karena dipengaruhi oleh tutupan lahan (vegetasi) dan pengaruh angin (Sanger 2016).

Tabel 8 Kerapatan vegetasi ruang terbuka hijau

\begin{tabular}{lcccc}
\hline \multicolumn{1}{c}{ Lokasi Penelitian } & Individu & Jenis & Famili & Kerapatan (ind/ha) \\
\hline Taman Flora & 41 & 8 & 5 & 117 \\
Kebun Bibit Wonorejo & 80 & 18 & 11 & 145 \\
Hutan Kota Balas Klumprik & 52 & 6 & 4 & 163 \\
\hline
\end{tabular}

Jumlah individu, jenis, dan famili terbanyak dimiliki oleh Kebun Bibit Wonorejo. Hal tersebut dikarenakan Kebun Bibit Wonorejo merupakan lokasi pembibitan untuk didistribusikan ke taman dan jalur hijau di seluruh Kota Surabaya sehingga terdapat berbagai jenis tumbuhan dari berbagai famili terutama tanaman hias dan tanaman peneduh. Tanaman yang paling banyak ditemukan di Taman Flora adalah angsana (Pterocarcus indicus). Lokasi taman flora yang dekat dengan jalan menjadikan angsana cocok di tanam di taman flora. Tanaman angsana digunakan sebagai pelindung jalan dikarenakan angsana mampu mengakumulasikan $\mathrm{Pb}$ di daunnya (Yudha et al 2013). Tanaman yang paling banyak dijumpai di Kebun Bibit Wonorejo adalah Trembesi (Samanea saman), tanaman tersebut dijumpai hampir di setiap sudut Kebun Bibit Wonorejo. Bentuk tajuk Trembesi yang lebat dan melingkar memungkinkan untuk dijadikan sebagai tanaman pelindung (Bashri 2014). Hutan Kota Balas Klumprik ditemukan banyak tanaman Jabon (Anthocephalus cadamba), tanaman tersebut banyak ditemukan di pinggir kawasan ruang terbuka hijau. Hasil wawancara dengan pihak pengelola, tanaman jabon sudah ada sebelum Hutan Kota Balas Klumprik terbentuk, tanaman tersebut dijadikan masyarakat sekitar sebagai tanaman peneduh.

\section{Analisis Nilai Kenyamanan Termal di Dalam dan di Luar Ruang Terbuka Hijau}

Bagian dalam Taman Flora dan Kebun Bibit Wonorejo memiliki nilai THI sebesar $29{ }^{\circ} \mathrm{C}$ dan $28{ }^{\circ} \mathrm{C}$ yang berarti nilai tersebut menunjukkan bahwa kondisi tidak nyaman didalam Taman Flora dan Kebun Bibit Wonorejo. Diduga kondisi tersebut disebabkan lokasi Taman Flora dan Kebun Bibit Wonorejo berada di tengah kota dengan aktivitas yang memicu kenaikan suhunya banyak. Lokasi Taman Flora dan Kebun Bibit Wonorejo berada di tepi jalan raya yang terdapat pengeras jalan berupa aspal dan asap kendaraan. Lantai Taman Flora dan Kebun Bibit Wonorejo tertutupi oleh material aspal dan konblok. Vegetasi pohon yang ada di Taman Flora dan Kebun Bibit Wonorejo tidak semuanya menutupi lantai 
hutan. Bagian yang tidak tertutupi kanopi pohon tersebut langsung terkena radiasi sinar matahari, menurut Saputro (2010) radiasi matahari akan langsung memanaskan permukaan pengeras dan selanjutnya memanaskan suhu udara diatasnya dikarenakan panas jenis udara lebih rendah daripada perkerasan atau konblok. Namun, dibandingkan nilai THI di luar Taman Flora dan Kebun Bibit Wonorejo nilai THI di dalam termasuk rendah hal tersebut karena adanya peran pohon yang menurunkan suhu di dalam kawasan. Penentuan nilai THI dari Hutan Kota Balas Klumprik, Taman Flora, dan Kebun Bibit Wonorejo menggunakan rumus Niewolt and Mc Gregor (1998) yaitu Temperature Humidity Index (THI). Klasifikasi nilai nyaman, cukup nyaman, dan tidak nyaman terhadap keberadaan RTH berdasarkan nilai THI terdapat pada Tabel 3. Hasil perhitungan terkait THI Taman Flora, Kebun Bibit Wonorejo, dan Hutan Balas Klumprik terlihat pada Gambar 20.

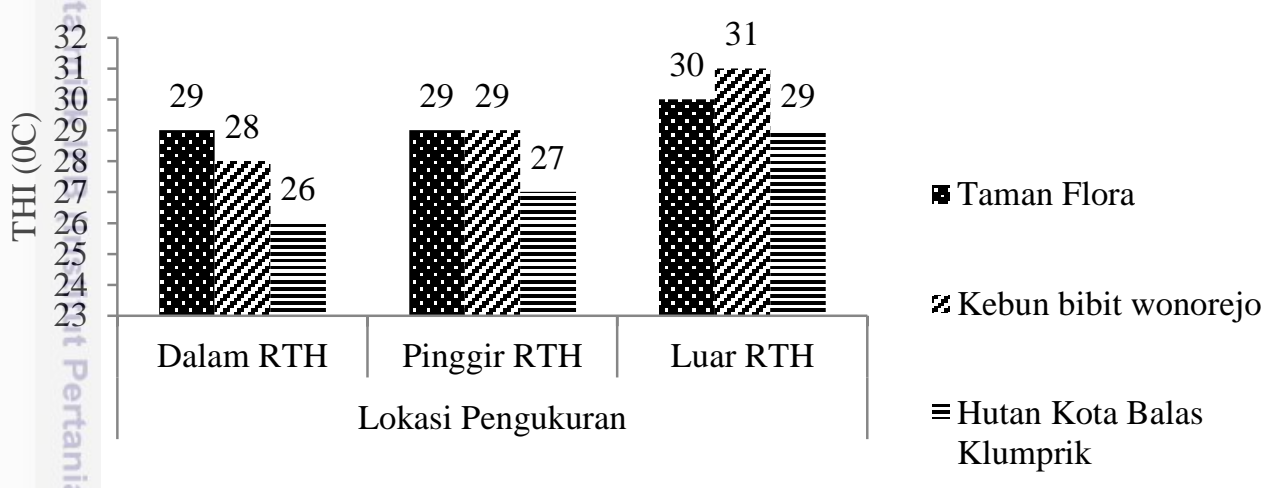

Gambar 20 Nilai THI di RTH

Berbeda dengan Taman Flora dan Kebun Bibit Wonorejo, dalam Hutan Kota Balas Klumprik memiliki nilai THI sebesar $26{ }^{\circ} \mathrm{C}$ yang berarti kondisi tersebut dinyatakan cukup nyaman. Kondisi cukup nyaman tersebut dikarenakan bagian lantai Hutan Kota Balas Klumprik tidak didominasi oleh pengeras dan konblok, lantai hutan masih berupa tanah, rumput liar, dan tajuk pohon yang menutupi seluruh area Hutan Kota Balas Klumprik seperti yang terlihat pada Gambar 21. Daun-daun pada tegakan pohon di hutan kota berperan sebagai pengahalang panas radiasi dan memberi efek penyejukan terhadap iklim mikro di bawah kanopi hutan kota (Dahlan 2004).
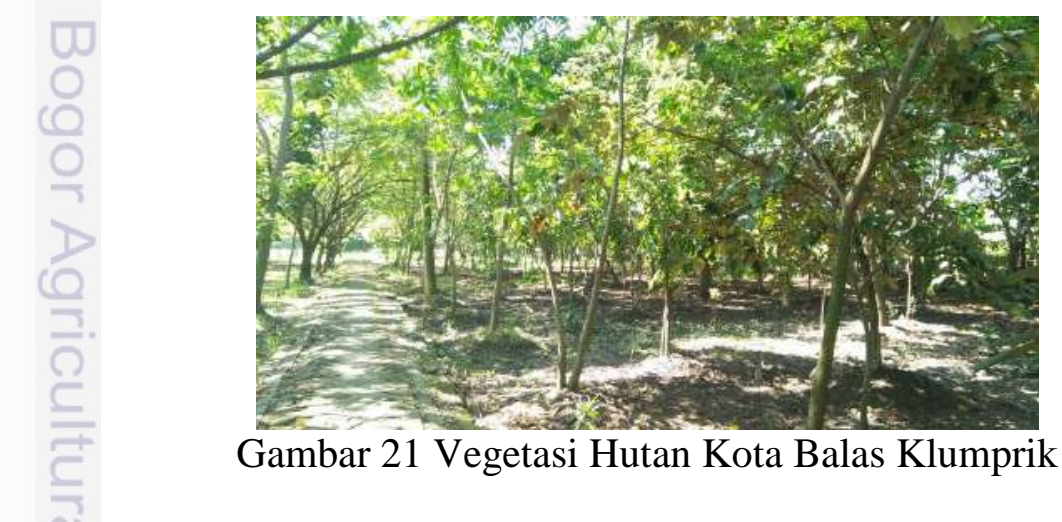

Bagian pinggir Taman Flora, Kebun Bibit Wonorejo dan Hutan Kota Balas Klumprik memiliki nilai THI sebesar $29{ }^{\circ} \mathrm{C}, 29{ }^{\circ} \mathrm{C}, 27{ }^{\circ} \mathrm{C}$. Kondisi tersebut 
menunjukkan bahwa pinggir ruang terbuka hijau ketiga lokasi termasuk kategori tidak nyaman. Kondisi tidak nyaman tersebut dimungkinkan karena bagian pinggir ruang terbuka hijau tidak terlalu banyak vegetasi pohonnya dibandingkan di dalam ruang terbuka hijau. Sementara itu bagian luar ruang terbuka hijau Taman Flora, Kebun Bibit Wonorejo dn Hutan Kota Balas Klumprik memiliki nilai THI sebesar $30{ }^{\circ} \mathrm{C}, 31{ }^{\circ} \mathrm{C}$, dan $29{ }^{\circ} \mathrm{C}$. Nilai tersebut menunjukan bahwa kondisi di luar ruang terbuka hijau termasuk kategori tidak nyaman. Kondisi tersebut dikarenakan tidak adanya naungan terhadap lingkungan di luar ruang terbuka hiijau, selain itu di luar ruang terbuka hijau dikelilingi oleh jalan raya, bangunan pertokaan, dan pemukiman penduduk yang menyebabkan terpapar radiasi matahari langsung yang akan menaikan suhu udara di sekitarnya. Hasil penelitian Aprihatmoko (2013) kawasan non-RTH memiliki nilai yang selalu lebih tinggi dripada di kawasan RTH, suhu udara yang lebih panas memberikan kenyamanan yang lebih buruk disebabkan kawasan non-RTH tidak adanya penghalang radiasi yang masuk sehingga radiasi yang datang langsung diterima oleh permukaan.

\section{Persepsi dan Preferensi Pengunjung Ruang Terbuka Hijau}

Jumlah responden yang diwawancarai ialah sebanyak 30 orang dimana dimasing-masing ruang terbuka hijau sebanyak 10 orang. Responden mayoritas adalah laki-laki sebanyak 19 orang dan perempuan sebanyak 11 orang. Usia responden yang paling banyak diwawancarai ialah rentang 13-19 tahun dan 25-55 tahun yaitu sebanyak 9 orang. Tingkat pendidikan responden yang dijumpai paling banyak ialah perguruan tinggi sebanyak 14 orang, dan SMA/sederajat sebanyak 10 orang. Mayoritas responden yang diwawancarai berprofesi sebagai karyawan swasta sebanyak 12 orang dan pelajar sebanyak 11 orang. Mayoritas responden sebanyak 18 orang merupakan pendapatang di Kota Surabaya, persentase identitas responden terdapat pada Lampiran 2. Keberadaan pengunjung di dalam kawasan ruang terbuka hijau dinilai penting untuk menilai kenyamanan yang terdapat di dalam RTH. Menurut Mariski et al.(2017) kenyamanan pengunjung di area taman merupakan persyaratan dasar guna menunjang aktivitas di taman, pengunjung mengaharapkan kenyamanan yang ideal termasuk kenyamanan klimatologis.

\section{Persepsi Pengunjung Terhadap Kenyamanan Termal di Ruang Terbuka Hijau}

Persepsi diartikan sebagai penafsiran terhadap objek di lingkungan yang diserap oleh indra manusia sebagai stimulus yang dilanjutkan ke otak yang menghasilkan penilaian terhadap objek tersebut (Kartikasari et al 2014). Terdapat perbedaan persepsi antara satu individu dengan individu yang lain, dimana persepsi yang diberikan dipengaruhi oleh objek yang diamati dalam hal ini vegetasi RTH, kedalaman pengamatan yang dilakukan serta faktor pribadi dari individu itu sendiri (Kartika et al.2014). Pengambilan data persepsi pengunjung terhadap RTH dilakukan dengan memberikan kuisioner kepada pengunjung yang ditemui di dalam RTH. Berikut hasil dari kuisioner yang diberikan kepada pengunjung (Gambar 22, 23 dan 24). 


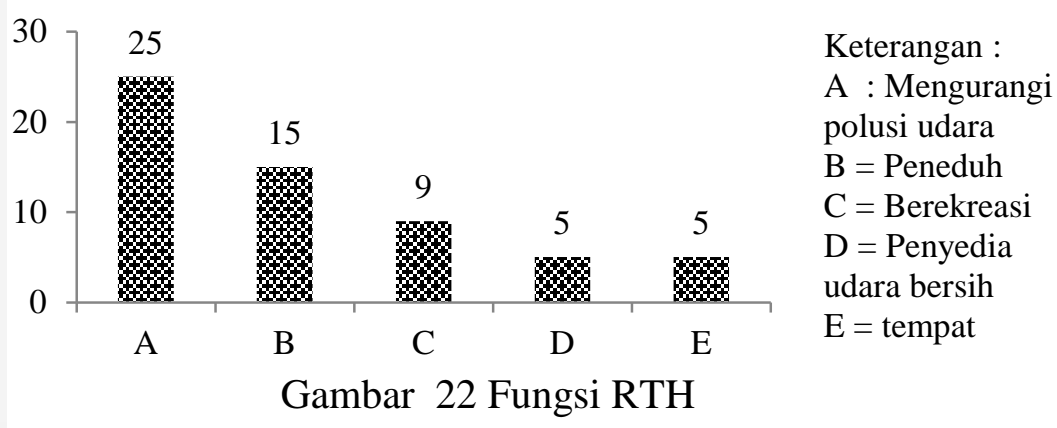

Hasil wawancara dengan responden melalui kuisioner didapatakan bahwa responden berpendapat bahwa ruang terbuka hijau memiliki fungsi untuk mengurangi polusi udara. Selain itu responden juga berpendapat bahwa keberadaan ruang terbuka hijau peneduh sehingga terhindar dari sinar matahari karena sinar matahari mengenai permukaan daun. Responden juga berpendapat ruang terbuka hijau berfungsi sebagai tempat berekreasi melepas penat, tempat besosialisasi seperti kegiatan gathering, reunian, atau arena bermain. Penanaman tumbuhan atau vegetasi berkayu dapat memberikan manfaat lingkungan dalam manfaat proteksi, estetika, rekreasi, penghasil $\mathrm{O}_{2}$ dan kegunaan khusus lainnya (Saraswati 2008).

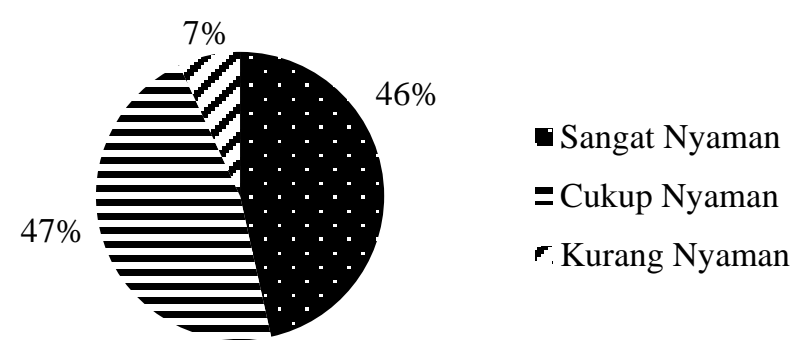

Gambar 23 Tingkat kenyamanan menurut pengunjung

Hasil wawancara menemukan bahwa responden yang berpendapat bahwa ruang terbuka hijau sangat nyaman sebanyak $46 \%$, cukup nyaman sebanyak $47 \%$, dan yang berpendapat kurang nyaman sebanyak $7 \%$. Banyaknya responden menilai bahwa ruang terbuka hijau sangat nyaman atau cukup nyaman karena responden berada di bawah naungan pohon yang menjadi salah satu faktor merasa nyaman sehingga terhindar dari radiasi matahari dan suhu yang tidak terlalu tinggi.

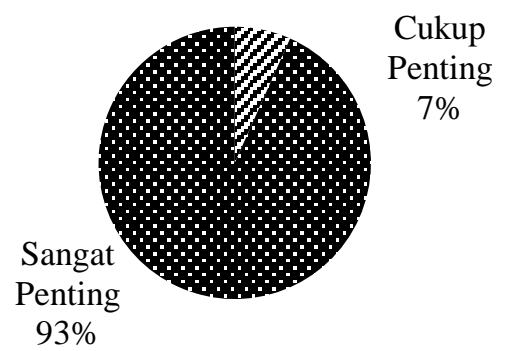

Gambar 24 Pendapat pengunjung seberapa penting RTH 
Sebanyak 93\% responden menilai keberadaan ruang terbuka hijau sangat penting untuk menurunkan suhu diperkotaan dan meningkatkan kenyamanan. Sementara $7 \%$ responden menilai keberadaan ruang terbuka hijau dinilai cukup penting. Ruang terbuka hijau dapat membantu meningkatkan kualitas lingkungan kota dan secara mikro dapat menciptakan kondisi yang nyaman dan ketercapaian keseimbangan antara lingkungan alam dan lingkungan binaan (Saraswati 2008).

\section{Preferensi Pengunjung Terhadap Ruang Terbuka Hijau}

Hasil wawancara yang dilakukan kepada 30 responden didapatkan bahwa pohon peneduh paling banyak dipilih oleh pengunjung sebagai elemen yang perlu ditambahkan pada ruang terbuka hijau. Keberadaan ruang terbuka hijau yang memiliki tumbuhan yang tertata rapi dengan berbagai jenis tanaman dan fasilitas pendukung merupakan penataan yang diharapkan oleh responden. Responden mengharapkan manfaat RTH berupa nilai kenyamanan untuk menunjang kegiatan di dalam kawasan RTH. Preferensi responden merupakan sikap atas pilihan terhadap suatu yang dipengaruhi oleh faktor internal dan eksternal (Marselina et al.2014). Preferensi yang diambil adalah prefernsi terkait objek yang dapat ditambahkan dalam RTH, penataan tanaman yang diharapkan dalam RTH, serta manfaat RTH yang diharpakan kedepannya. Penjelasan terkait preferensi pengunjung terhadap RTH terdapat pada Gambar 25, 26, dan 27.

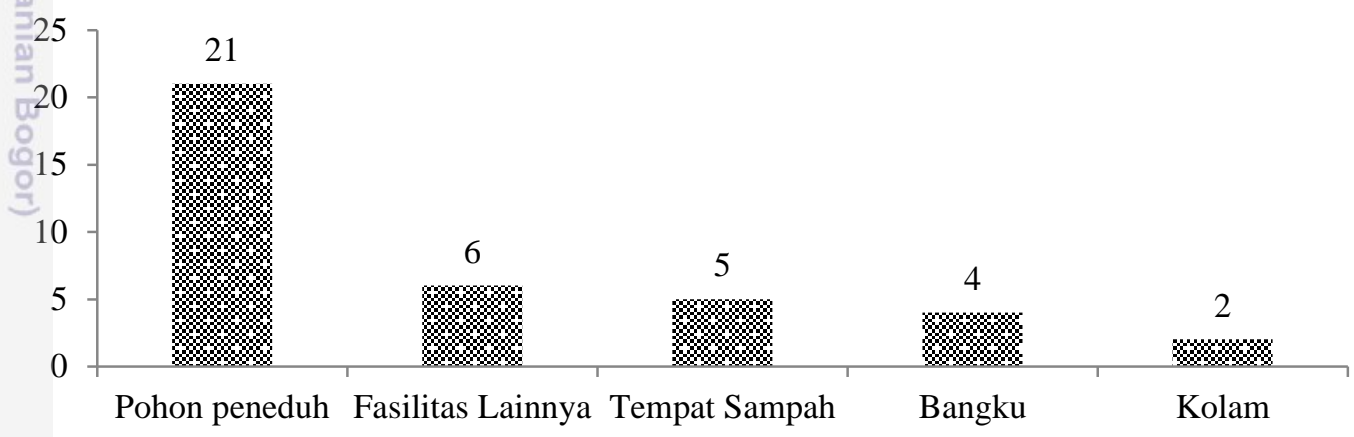

Gambar 25 Preferensi pengunjung terkait elemen yang perlu ditambahkan

Sebanyak 21 responden menilai perlu adanya penambahan pohon peneduh di dalam taman sehingga suhu di dalam ruang terbuka hijau semakin terasa nyaman. Pengunjung di Hutan Kota Balas Klumprik menilai perlunya adanya penambahan fasilitas di Hutan Kota Balas Klumprik berupa mushala, gazebo, tempat bermain anak, dan parkiran untuk pengunjung. Sementara di Kebun Bibit Wonorejo pengunjung menilai perlu adanya penambahan air mancur sebagai hiasan, dan fasiltas berupa toilet. Penambahan tempat sampah, bangku taman dan kolam merupakan fasilitas yang ingin pengunjung dapatkan. 


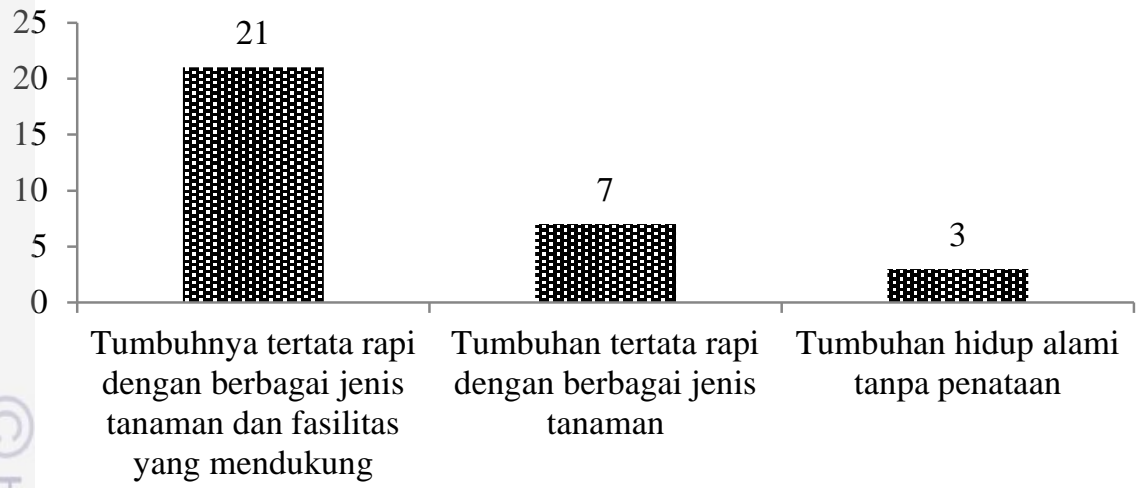

Gambar 26 Penataan RTH yang diharapkan

Pengunjung mengharapkan penataan taman dengan berbagai fasilitas yang mendukung keberadaan taman tersebut sehingga pengunjung bisa merasakan rasa nyaman saat berada di dalam ruang terbuka hijau. Sebanyak 7 responden menilai perlu a danya penataan taman dengan berbagai jenis taman sehingga adanya variasi jenis. Sementara 3 orang menilai ruang terbuka hijau akan lebih baik jika dibiarkan hidup alami tanpa penataan.

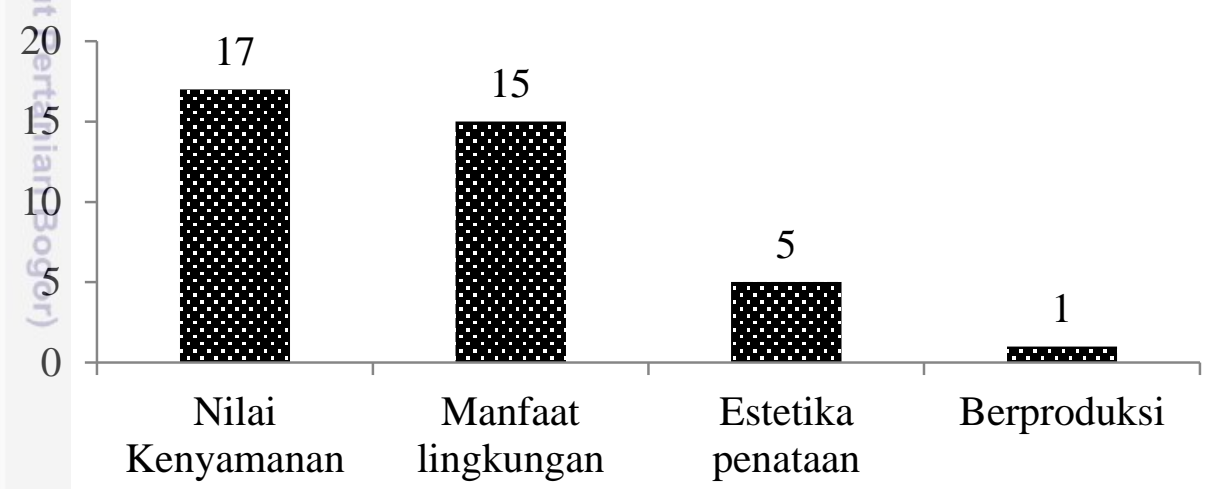

Gambar 27 Manfaat RTH yang diharapkan

Responden menilai nilai kenyamanan baik termal maupun audial sangat penting sebagai peran ruang terbuka hijau. Selain itu adanya manfaat lingkungan berupa udara bersih sangat diharapakan, penataan estetika berupa pemilihan tempat untuk fasilitas dan tanaman sangat penting. Estetika penataan yang diharapkan berupa adanya penataan terhadap pohon dan fasilitas taman. Ruang Terbuka Hijau yang berproduksi diharapkan berupa buah yang bisa diambil. Untuk mengwujudkan manfaat ruang terbuka hijau tersebut maka perlu adanya penataan di dalam kawasan menurut Irwan (2005) hutan kota dapat memberikan kenyamanan dan kenikmatan kepada penduduk kota jika kita dapat mengembangkan dan membangun hutan kota yang berstrata dengan keanekaragaman jenis dan jumlah yang banyak serta ditata dengan baik.

\section{Pengembangan Ruang Terbuka Hijau}

Kondisi vegetasi Ruang Terbuka Hijau Taman Flora, Kebun Bibit Wonorejo, dan Hutan Kota Balas Klumprik mampu memberikan efek penurunan 
suhu udara di dalam kawasan sehingga memberikan rasa nyaman bagi pengunjung. Namun, kondisi suhu di luar ruang terbuka hijau masih tergolong tinggi sehingga memberikan efek tidak nyaman bagi lingkungan sekitarnya. Suhu di dalam Taman Flora, Kebun Bibit Wonorejo dan Hutan Kota Balas Klumprik sedikit tinggi hal tersebut disebabkan adanya material pengeras di dalam ruang terbuka hijau dan adanya lantai taman yang tidak tertutupi tajuk sehingga radiasi matahari masuk ke dalam lantai taman dan diserap langsunng sehinga terjadinya peningkatan suhu. Upaya agar ruang terbuka hijau dapat maksimal memberikan fungsi dalam penurunan suhu perkotaan adalah dengan dilakukan penambahan jenis tanaman, penambahan fasilitas, dan penataannya.

Penambahan jenis tanaman harus disesuaikan dengan kondisi lingkungan tempat tumbuh dan manfaat yang akan diberikan. Menurut Dahlan (2004) pemilihan jenis pohon perlu memperhatikan beberapa hal seperti : (1) jenis yang ditanam dapat tumbuh baik sesuai kondisi iklim dan tanah, (2) jenis pohon yang ditanami merupakan jenis yang toleran terhadap keadaan alami setempat, (3) pohon yang ditanam memiliki fungsi dalam mengelola masalah lingkungan setempat dengan efektif dan efisien, dan (4) jenis yang ditanami diusahakan jenis yang ikut berpartisipasi dalam mengurangi masalah lingkungan global, seperti efek rumah kaca. Bentuk dan luasan tajuk pohon merupakan salah satu kategori yang harus diperhatikan dalam penambahan jenis tanaman. Tajuk yang lebar akan sangat baik dalam peneduhan yang memberi efek penurunan suhu.

Penambahan jenis pohon yang memiliki tajuk lebar seperti Angsana (Pterocarpus indicus), Trembesi (Samanea saman), Glodokan Tiang (Polyalthia longifolia), Kupu-kupu (Bauhinia purpurea), Krey Payung (Felicium decipiens), Beringin (Ficus benjamina), Mahoni (Swietenia macrophylla), Flamboyan (Delonix regia), Tanjung (Mimusops elengi), Ketapang (Terminalia cattapa), Bungur (Lagerstomia speciosa), ketapang (Terminalia cattapa) dan Asam Jawa (Tamarindus indica). Jenis tersebut ada yang sudah tersedia di Taman Flora, Kebun Bibit Wonorejo dan Hutan Kota Balas Klumprik dan ada yang belum tersedia. Jenis tersebut menurut Sari (2013) memiliki potensi sebagai ameliorasi iklim mikro sehingga dapat membantu dalam perbaikan iklim mikro disekiatarnya. Jenis Angsana, Glodokan Tiang, Mahoni, dan Tanjung memiliki fungsi penahan dan penyaring gas dan partikel padat udara serta penghasil oksigen (Bramasto et al. 2006). Jenis Flamboyan, Bungur dan Ketapang berfungsi sebagai ameliorasi iklim/peneduh jalan dan peredam kebisingan (Bramasto et al. 2006).

Penataan Hutan Kota Balas Klumprik dilakukan dengan penambahan fasillitas di dalam kawasan seperti arena bermain anak-anak, mushala, toilet umum serta tempat parkir. Selain itu, pembuatan jalur jalan didalam kawasan untuk pengunjung, mengingat Hutan Kota Balas Klumprik sangat luas sehingga semua area dalam kawasan dapat dikunjungi oleh pengunjung. Penataan jenis tanaman peneduh dan buahan di dalam kawasan juga perlu dilakukan sehinngga dapat menutupi area lantai huta kota. Hutan Kota Balas Klumprik, Taman flora, dan Kebun Bibit Wonorejo merupakan ruang terbuka publik yang banyak dikunjungi oleh masyarakat untuk itu perlu adanya penataan fasilitas dan tanaman untuk menunjang kenyamanan pengunjung. Menurut Gunawan (2005) aspek kenyamanan pada RTH publik adalah mampu memperbaiki iklim mikro kota sehingga masyarakat nyaman untuk beraktivitas di dalam maupun di sekitar taman 
publik. Berikut contoh sketsa penataan pohon yang memberikan kenyamanan pada Gambar 27.

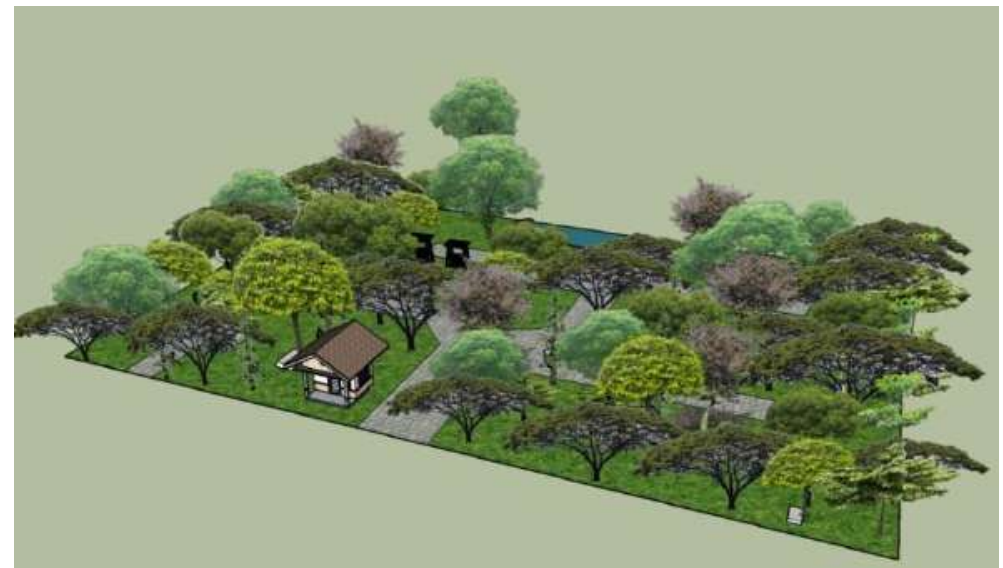

Gambar 28 Sketsa penataan tanaman di RTH

Pada sketsa tersebut terlihat bahwa adanya strata vegetasi di dalam RTH. Menurut Irwan (2005) hutan kota yang berbentuk menyebar strata banyak dengan komunitas vegetasi menyerupai hutan akan lebih efektif menanggulangi masalah lingkungan kota. Penanaman jenis tumbuhan dalam memberikan efek penurunan suhu tidak hanya dilakukan di dalam ruang terbuka hijau saja namun juga di area terbuka lain di luar ruang tebuka hijau. Area yang bisa dimanfaatkan dalam membantu menurunkan suhu dan memberi rasa nyaman seperti pekarangan rumah. Area pekarangan dapat ditanami berbagai jenis tumbuhan sebagai tanaman peneduh dan dapat juga dimanfaatkan hasilnya seperti tanaman buah, penanaman tanaman disesuaikan dengan luas pekarangan. Tanaman buah yang bisa ditanam merupakan jenis tanaman buah dengan tajuk lebar seperti manga (Mangifera indica), kersen (Muntingia calabura), rambutan (Nephelium lappaceum), jambu biji (Psidium guajava), dan sirsak (Annona muricata) hal tersebut dilakukan agar suhu di perkotaan tidak semakin panas.

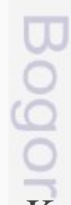

\section{SIMPULAN DAN SARAN}

\section{Simpulan}

Kawasan di dalam dan di luar Taman Flora termasuk kategori tidak nyaman, suhu udara di dalam kawasan termasuk tinggi. Kerapatan vegetasi Taman Flora adalah sebeasar 117 individu/ha. Suhu udara semakin jauh dari Taman Flora terjadi peningkatan dari 1-4 derajat ketitik terjauh dari Taman Flora. Sementara untuk kelembapan udara Taman Flora semakin jauh dari lokasi Taman Flora kelembapan semakin menurunan yaitu 8-14\% ke titik terjauh Taman Flora.

Kebun Bibit Wonorejo memiliki kerapatan vegetasi 145 ind/ha dimana di dalam kawasan terdapat berbagai jenis tanaman dari berbagai famili. Kawasan dalam dan luar Kebun Bibit Wonorejo termasuk kategori tidak nyaman. 
Peningkatan suhu udara dari dalam hingga ke luar titik terjauh Kebun Bibit Wonorejo adalah 1-2 derajat. Penurunan kelembapan udara dari dalam hingga keluar kebun bibit adalah 2-17\%.

Hutan Kota Balas Klumprik memiliki kerapatan vegetasi sebebsar 163 ind/ha. Kondisi didalam kawasan hutan kota tergolong dalam kondisi cukupp nyaman, sementara untuk diluar hutan kota hingga titik terjauh adalah 1-5 derajat. Kelembapan udara hutan kota balas klumprik mengalami penurunan dari dalam hingga keluar hutan kota sebeasar 1-10\%.

Adanya hubungan perubahan jarak dari dalam hingga keluar RTH terhadap perubahan suhu, kelembapan, dan kenyamanan termal. Semakin menjauhi RTH suhu semakin meningkat, kelembapan menurun serta kenyamanan meningkat. Menurut pengunjung keberadaaan RTH telah mampu memberikan rasa nyaman sehingga dapat menunjang berbagai kegiatan yang dilakukan di daalm RTH.

\section{Saran}

Perlu adanya penambahan pohon di dalam Taman Flora, Kebun Bibit Wonorejo dan Hutan Kota Balas Klumprik. Jenis tanaman berupa tanaman dengan tajuk lebar dan lebat sehingga dapat menutupi lantai ruang terbuka hijau. Perlu adanya penelitian lanjutan terkait persepsi dan referensi ruang terbuka hijau menurut masyarakat sekitar ruang terbuka hijau. Perlu adanya penelitian terkait efektivitas tajuk tanaman seperti apa yang mampu memberi efek penurunan suhu ưdara yang baik. 


\section{DAFTAR PUSTAKA}

Abbott P F and Tabony R C. 1985. The Estimation Of Humandity Parameters [internet]. [diacu 2018 Juli 11]. Tersedia dari : https://www.researchgate.net/publication/285534387_The_estimation_of_hu midity_parameters.

Ainy CN. 2012. Pengaruh ruang terbuka hijau terhadap iklim mikro di kawasan Kota Bogor [skripsi]. Bogor (ID): Institut Pertanian Bogor.

Aprihatmoko F. 2013. Analisis hubungan antara ruang terbuka hijau (RTH) dan indeks kenyamanan, studi kasus Kota Yogyakarta [skripsi]. Bogor (ID) : Institut Pertanian Bogor

Bashri-A, Utami B, Primandiri P R. 2014. Pertumbuhan bibit trembesi (Samanea saman) dengan inokulasi cendawan mikoriza arbuskula pada media bekas tempat pembuangan akhir (tpa) Klotok Kediri. Prosiding Seminar Biologi. Surakarta (ID) : FKIP UNS

Bramosto Y; Nushasyibi; Danu; Syamsuwida D; Zanzibar M; Pujiastuti E; Mokodompit S. Trees OF City Profil Tanaman Hutan untuk Perkotaan Wilayah Jawa Barat, Banten, dan DKI Jakarta. Bogor (ID): Balai Penelitian Teknologi Perbenihan Tanaman Hutan.

Dahlan EN. 2004. Membangun Kota Kebun (Garden City) Bernuansa Hutan Kota. Bogor (ID): IPB Press.

Danner M; Locherer M; Hank T; Richter K. 2015. Measuring Leaf Area Index (LAI) with the LI-Cor LAI 2200C or LAI-2200 (+2200Clear Kit). Postdam (DE): Enmap Consortium

Djumhaer M. 2003. Pendugaan leaf area index dan luas bidang dasar tegakan dengan menggunakan landsat $7 \mathrm{etm}+$ [skripsi]. Bogor (ID): Institut Pertanian Bogor.

Dyah I Ratihw, Kurniawan Eddi B, Usman. 2010. Penataan pemukiman di kawasan segiempat tunjungan kota surabaya. Jurnal Tata Kota Dan Daerah. Vol (02):1-8

Emmanuel R. 2005. Thermal comfort implications of urbanization in a warmhumid city: the colombo metropolitan region (CMR), Sri Lanka. $J$ Building And Evironment. 40:1591-1601.

Fadholi A. 2013. Study pengaruh suhu dan tekanan udara terhadap operasi penerbangan di bandara H.A.S. Hananjoeddin Buluh Tumbang Belitung periode 1980-2010. JPFA. 3(1):1-10.

Fadholi A. 2013. Pemanfaatan suhu udara dan kelembapan udara dalam persamaan regresi untuk simulasi prediksi total hujan bulanan di Pangkal Pinang. J Cauchy. 3(1): 1-9.

Gomez F, Gil L, Jabaloyes J. 2004. Experimental investigation on the thermal comfort in the city: relationship with the green areas, interaction with the urban microclimate. J Building And Environment. 39: 1077-1086.

Gunawan, A. 2005. Evaluasi kualitas estetika lanskap Kota Bogor. J Lanskap Indonesia. Vol (1): 77-80

Handoko.1994. Klimatologi Dasar. Jakarta (ID) : Pusat Jaya

Handoko, Hidayati R, June T, Nasir AN. 1994. Klimatologi Dasar. Bogor (ID): Pustaka Jaya. 
Hidayat IW. 2010. The Ecological role of trees and their interactions in forming the microclimate amenity of environment. J Bumi Lestari. 10(2):182-190.

Imansari N, Khadiyanta P. 2015. Penyediaan hutan kota dan taman kota sebagai ruang terbuka hijau (rth) publik menurut preferensi masyarakat di kawasan pusat Kota Tangerang. J Ruang. 1(3): 101-110.

Irwan ZD. 2005. Tantangan Lingkungan dan Lansekap Hutan Kota. Jakarta (ID): Bumi Aksara.

Kartikasari M, Wahyono H. 2014. Persepsi masyarakat terhadap pemugaran tanaman mustika di Kota Blora sebagai ruang terbuka public. J Teknik PWK. 3(4):681-692.

Marselina R, Massadun. 2014. Tipologi rth privat berdasarkan preferensi penghuni di perumahan terencana dan perumahan tidak terencana (studi kasus : Kelurahan Gedawang Kota Semarang). J Teknik PWK. 3(4): 564575.

Mariski; Nasrullah N; Gunawan A. Persepsi dan preferensi pengunjung terhadap kenyamanan klimatologis di Taman Menteng dan Taman Honda Tebet. $J$ Lanskap Indonesia. 9(1): 24-35.

Nieuwolt S, Mc Gregor GR. 1998. Tropical climatology. England (UK): John Wiley \& Sons Ltd.

Nugroho AM, Ahmad MH, Ossen DR. 2007. A Preliminary study of thermal comfort in Malaysia's single storey terraced house. JAABE. 6(1): 175-182.

Oliveira S, Andrade H, Vaz T. 2011. The Cooling effect of green spaces as a contribution to the mitigation of urban heat: a case study in Lisbon. $J$ Building And Enivironment. Vol(46): 2186-2194.

Risdiyanto I, Setiawan R. 2007. Metode neraca energi untuk perhitungan indeks luas daun menggunakan data citra satelit multi spetral. J Agromet Indonesia. $21(2): 27-38$

Rushayati SB. 2012. Hubungan antara indeks luas daun dengan iklim mikro dan indeks kenyamanan. Media Konservasi. 17(3):143-148

Saraswati AA. 2008. Keberadaan ruang terbuka hijau dalam pembangunan kawasan industry. J Teknik Lingkungan. ISSN 1441-318X : 1-8.

Sari A N. 2013. Evaluasi hutan kota berdasarkan fungsi ameliorasi iklim mikro di kota semarang [skripsi]. Bogor (ID): Institut Pertanian Bogor

Sanger YYJ, Rogi J E.X, Rombang J. 2016. Pengaruh tipe tutupan lahan terhadap iklim mikro di Kota Bitung. J Agri Sosial Ekonomi Unsrat. Vol (12): 105116.

Saputro TH. 2010. Studi pengaruh area perkerasan terhadap perubahan suhu udara (Studi Kasus Area Pa

rkir Plaza Senayan, Sarinah Thamrin, dan Stasiun Gambir). J Lanskap Indonesia. Vol (2): 76-8.

Setiawan R. 2006. Metode neraca energi untuk perhitungan leaf area index (LAI) di lahan bervegetasi menggunakan citra satelit [skripsi]. Bogor (ID) : Institut Pertanian Bogor

Setiawan. 2014. Peran hutan kota dalam perbaikan iklim mikro di Kota Malang jawa timur [skripsi]. Bogor (ID) : Institut Pertanian Bogor.

Shahidan MF, Shariff MKM., Jones P, Shalleh E, Abdullah AM. 2010. A Comparison of mesua ferrea 1 . and hurra crepitans 1 . for shade creation and 
radiation modification in improving thermal comfort. $J$ Landscape And Urban Planning 97:168-181.

Sugiyono. 2011. Statistik Untuk Penelitian. Bandung (ID): Alfabeta

Sugiyono. 2013. Metode Penelitian Kombinasi (Mixed Methods). Bandung (ID): Penerbit Alfabet Bandung.

Sulistyantara B, T Yuritaka. 1995. Study on characteristics of green structure at urban area using the thermoscape analiysis. Bulletin Of Faculty Horticulture. Chiba (JP) : University Japan.

Tauhid. 2008. Kajian jarak jangkau vegetasi pohon terhadap suhu udara pada siang hari di perkotaan: studi kasus kawasan Simpang Lima Kota Semarang [thesis]. Semarang (ID): Program Studi Ilmu Lingkungan.

Turner DP, Briggs JM, Cohen WB, Fassnacht KS, Kennedy RE. 1999. Relationships between leaf area index and Landsat TM spectral vegetation indices across three temperate zone sites. Remote Sensing of Environment.70: 52-68.

Walpole RE. 1982. Pengantar Statistika Ed ke-3. Jakarta (ID): PT Gramedia Pusaka Utama.

Wibowo S. 1987. Persepsi pengunjung tentang lingkungan rekreasi dan beberapa factor yang mempengaruhi di Taman Mini Indonesia Indah dan Kebun Raya Cibodas [tesis]. Bogor (ID): Institut Pertanian Bogor.

Yudha G P, Noli Z A, Idris M. 2013. Pertumbuhan daun angsana (Pterocarpus indicus wild) dan akumulasi logam timbal (pb). J Biologi Universitas Andalas. 2(2): 2303-216.

Dwi. Staf Hutan Kota Balas Klumprik 30 April 2018. Wawancara terkait sejarah serta pengelolaan Hutan Kota Balas Klumprik, Kota Surabaya.

Yudi. Staf Kebun Bibit Wonorejo 17 Mei 2018. Wawancara terkait sejarah dan pengelolaan Kebun Bibit Wonorejo, Kota Surabaya. 


\section{LAMPIRAN}

\section{Lampiran 1 Kuisioner Terhadap Responden}

I. Indentitas Responden

Jenis Kelamin

Asal

Umur

Pekerjaan

Tingkat pendidikan

II. Persepsi Pengunjung

1. Apakah Fungsi ruang Terbuka Hijau menurut anda?

1. Sebagai peneduh / penyerap sinar matahari

2. Penyedia udara bersih

3. Berekreasi

4. Mengurangi polusi udara yang disebabkan asap kendaraan

5. Tempat bersosialisasi

2. Seperti apakah bentuk penataan ruang terbuka hijau yang baik menurut anda?

1. Tanaman yang ditanam tanpa adanya pengaturan penataannya

2. Tanaman yang ditanam dengan penataan rapi dan adanya jarak antar tanamannya

3. Tanaman yang ditata rapi dengan fasilitas public yang menunjang.

4. Menurut anda bagaimana ketersedian ruang terbuka hijau di Kota Surabaya?

1. Kurang banyak

2. Cukup banyak

3. Sangat banyak

5. Apakah anda sudah merasa nyaman berada disekitar ruang terbuka hijau?

1. Kurang Nyaman

2. Cukup Nyaman

3. Sangat Nyaman

6. Apakah suhu disekitar ruang terbuka hijau sudah terasa nyaman?

1. Kurang Nyaman

2. Cukup Nyaman

3. Sangat Nyaman

7. Apakah Kelembapan disekitar ruang terbuka hijau telah memberikan rasa nyaman bagi anda?

1. Kurang Nyaman

2. Cukup Nyaman

3. Sangat Nyaman

8. Apakah keberadaan ruang terbuka hijau memebri pengaruh posistif terhadap kegiatan yang anda lakukan?

1. Ya

2. Tidak

9. Apakah penataan ruang terbuka hijau sudah sesuai dari segi keteduhan menurut anda?

1. Ya 
2. Tidak

10. Menurur anda seberapa penting keberadaan ruang tebruka hijau di Kota Surabaya?

1. Tidak penting

2. Kurang penting

3. Sangat penting

11. Apakah menurut anda keberadaan vegetasi di ruang terbuka hijau sudah cukup untuk memberikan rasa nyaman saat berada di sekitar kawasan ruang terbuka hijau?

1. Tidak cukup

2. Kurang cukup

3. Sangat cukup

12.-Menurut anda apa jenis tanaman yang memberikan kenyamanan?

1. Pohon

2. Perdu

3. Semak

4. Rumput

III. Preferensi Pengunjung

1. Apakah elemn ruang terbuka hijau yang pelru ditambahkan?

1. Pohon peneduh

2. Tempat sampah

3. Tempat duduk

4. Kolam

5. Fasilitaa lainnya.......

2. Penataan ruang terbuka hijau yang anda harapakan?

1. Tumbuhannya hidup alami tanpa penataan

2. Tumbuhannya hidup tertata dengan jenis tanamn yang beragam

3. Tumbuhannya hidup tertatat dengan berbagai jenis tanaman dan fasilitas pendukung

3. Dalam ruang terbuka hijau manfaat apa yang anda inginkan?

1. Kenyamanan yang paling penting

2. Berproduksi sehingga dapat dipanen hasilnya

3. Pentaan dengan estetika yang bagus

4. Manfaat lingkungan

4. Tipe tanaman yang memberikan rasa nyaman?

1. Pohon berdaun lebat

2. Pohon berdaun jarang

3. Semak

4. Rumput 


\section{Lampiran 2 Identitas Responden}

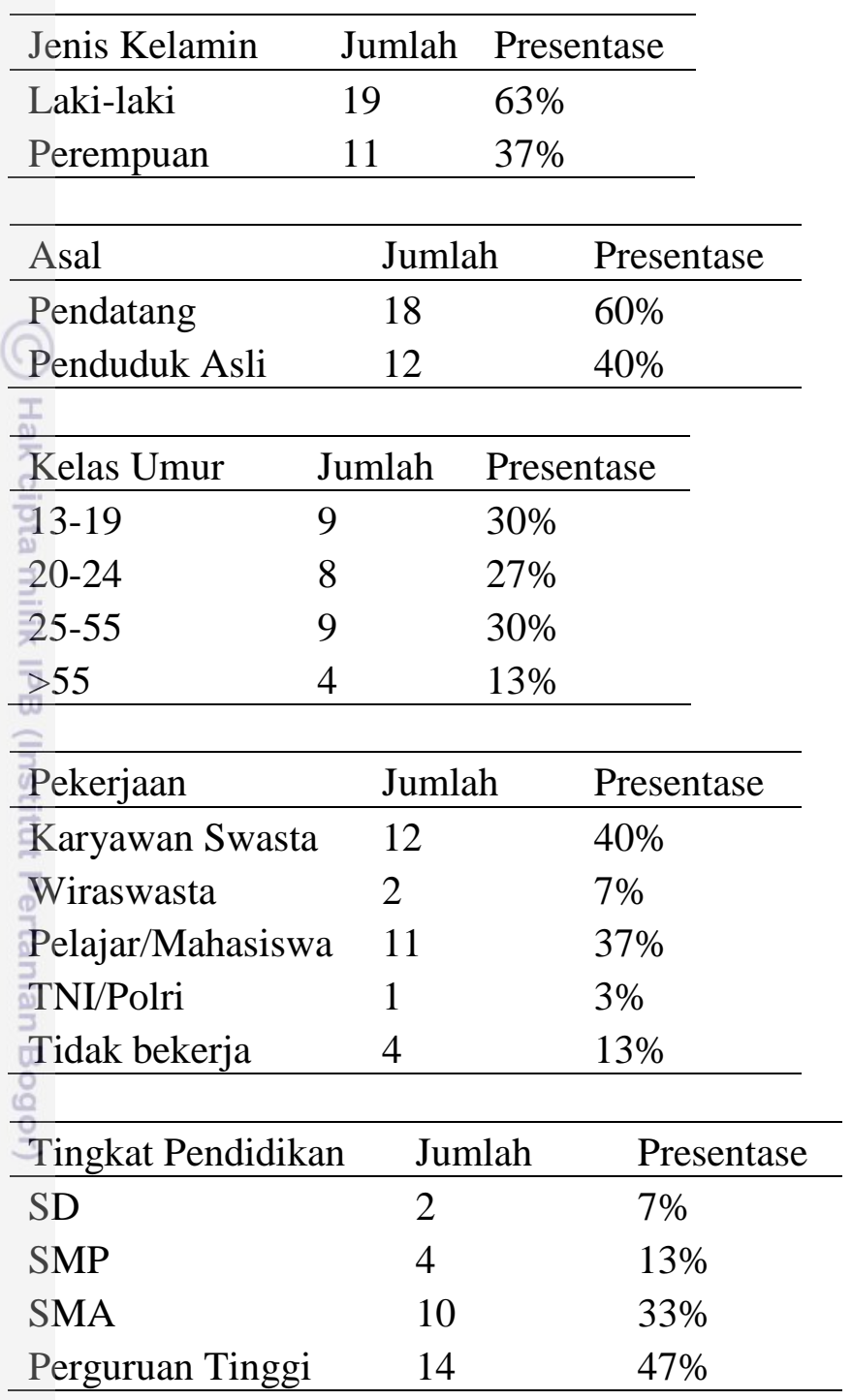

Lampiran 3 Kerapatan Taman Flora

\begin{tabular}{|c|c|c|c|c|}
\hline No & Nama Lokal & Nama Ilmiah & Famili & Kerapatan \\
\hline 1 & Cemara Angin & Casuarina equisetifolia & Casuarinaceae & 22.2222222 \\
\hline 2 & Flamboyan & Delonix regia & Fabaceae & 30.5555556 \\
\hline 3 & Angsana & Pterocarpus indicus & Fabaceae & 41.6666667 \\
\hline 4 & Tanjung & Mimusops elengi & Sapotaceae & 2.77777778 \\
\hline 5 & Glodokan Tiang & Polyalthia longifolia & Annonaceae & 2.77777778 \\
\hline 6 & Sawo Duren & Chrysophyllum cainito & Sapotaceae & 2.77777778 \\
\hline 7. & Pulai & Alstonia scholaris & Apocynaceae & 2.77777778 \\
\hline 8 & Trembesi & Samanea saman & Fabaceae & 8.33333333 \\
\hline
\end{tabular}




\section{Lampiran 4 Kerapatan Kebun Bibit Wonorejo}

\begin{tabular}{lllll}
\hline No & Nama Lokal & Nama Ilmiah & Famili & Kerapatan \\
\hline 1 & Trembesi & Samanea saman & Fabaceae & 30.769231 \\
2 & Glodokan Tiang & Polyalthia longifolia & Annonaceae & 7.6923077 \\
3 & Beringin & Ficus benjamina & Moraceae & 3.8461538 \\
4 & Jati & Tectona grandis & Lamiaceae & 21.153846 \\
5 & Mahoni & Swietenia mahagoni & Meliaceae & 13.461538 \\
6 & Angsana & Pterocarpus indicus & Fabaceae & 15.384615 \\
7 & Kedawung & Parkia timoriana & Fabaceae & 1.9230769 \\
8 & Tanjung & Mimusops elengi & Sapotaceae & 5.7692308 \\
9 & Johar & Senna siamea & Fabaceae & 7.6923077 \\
10 & Ketapang & Terminalia catappa & Combrotaceae & 1.9230769 \\
11 & Asam Jawa & Tamarindus indica & Fabaceae & 5.7692308 \\
12 & Flamboyan & Delonix regia & Fabaceae & 9.6153846 \\
13 & Belimbing & Averrhoa carambola & Oxalidaceae & 1.9230769 \\
14 & Kelengkeng & Dimocarpus longan & Sapindaceae & 3.8461538 \\
15 & Pulai & Alstonia scholaris & Apocynaceae & 3.8461538 \\
16 & Kupu-kupu & Bauhinia purpurea & Fabaceae & 1.9230769 \\
17 & Bayur & Pterospermum javanicum & Malvaceae & 1.9230769 \\
18 & Sawo duren & Chrysophyllum cainito & Sapotaceae & 1.9230769 \\
\hline
\end{tabular}

\section{Lampiran 5 Kerapatan Hutan Kota Balas Klumprik}

\begin{tabular}{lllll}
\hline No & Nama Lokal & Nama Ilmiah & Famili & Kerapatan \\
\hline 1 & Trembesi & Samanea saman & Fabaceae & 22.5 \\
2 & Jabon & Neolamarckia cadamba & Rubiaceae & 67.5 \\
3 & Flamboyan & Delonix regia & Fabaceae & 25 \\
4 & Kalpataru & Baringtonnia asiatica & Euphorbiaceae & 10 \\
5 & Angsana & Pterocarpus indicus & Fabaceae & 2.5 \\
6 & Kecurutan & Spathodea campanulata & Malvaceae & 2.5 \\
\hline
\end{tabular}




\section{Lampiran 6 Profil tajuk didalam RTH}

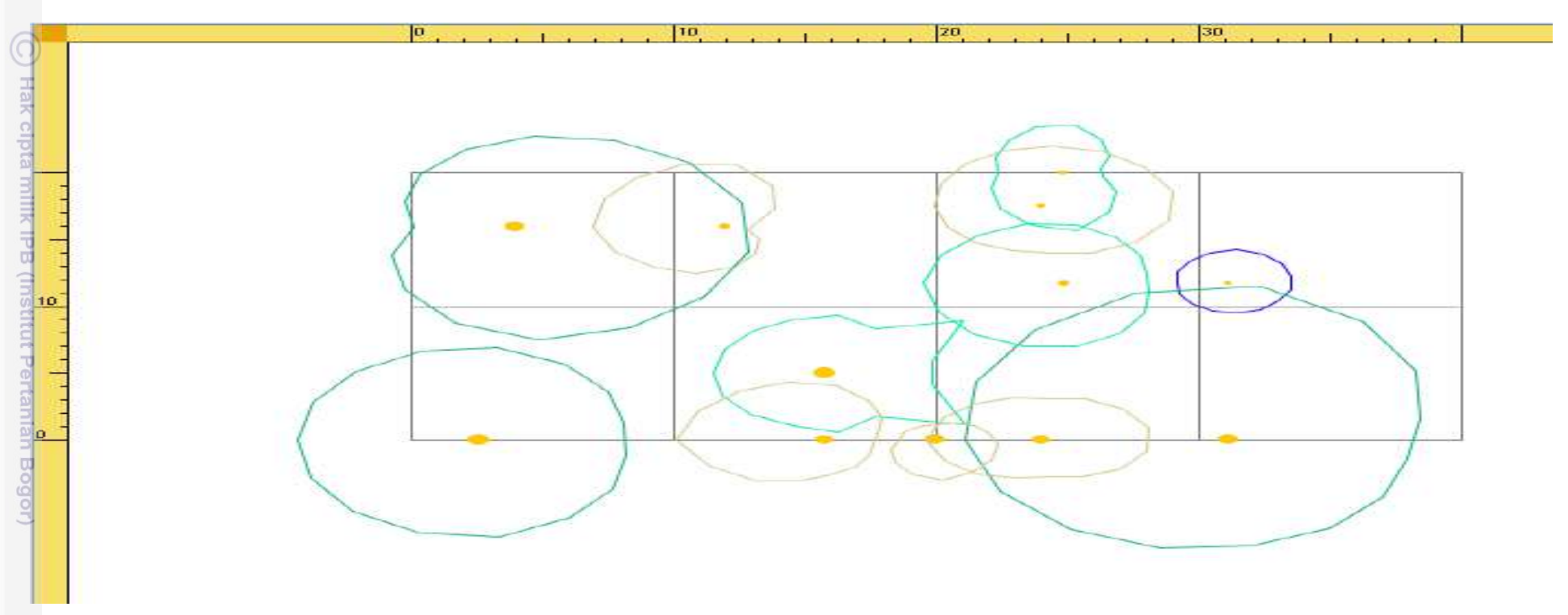




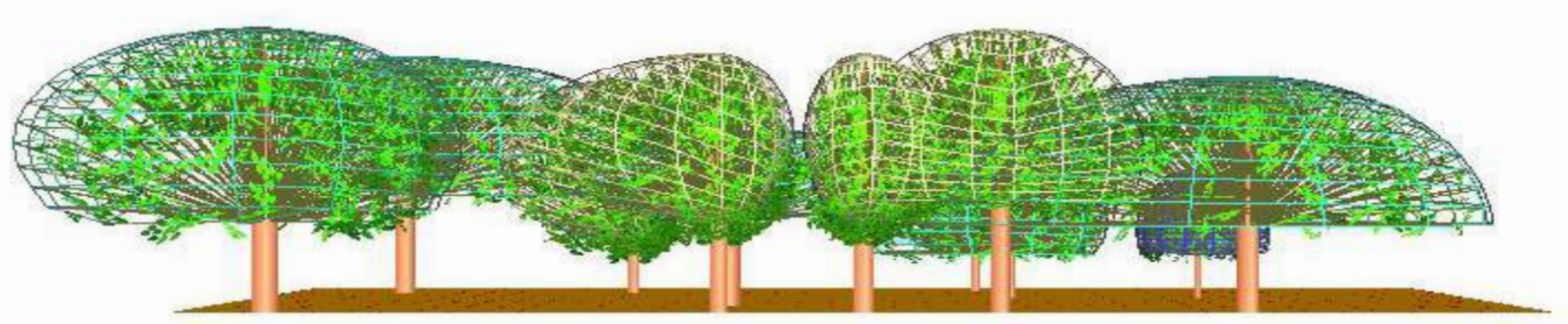

Taman Flora
Species Component

- Cemara

vanjung

Angsana

Flamboyan 


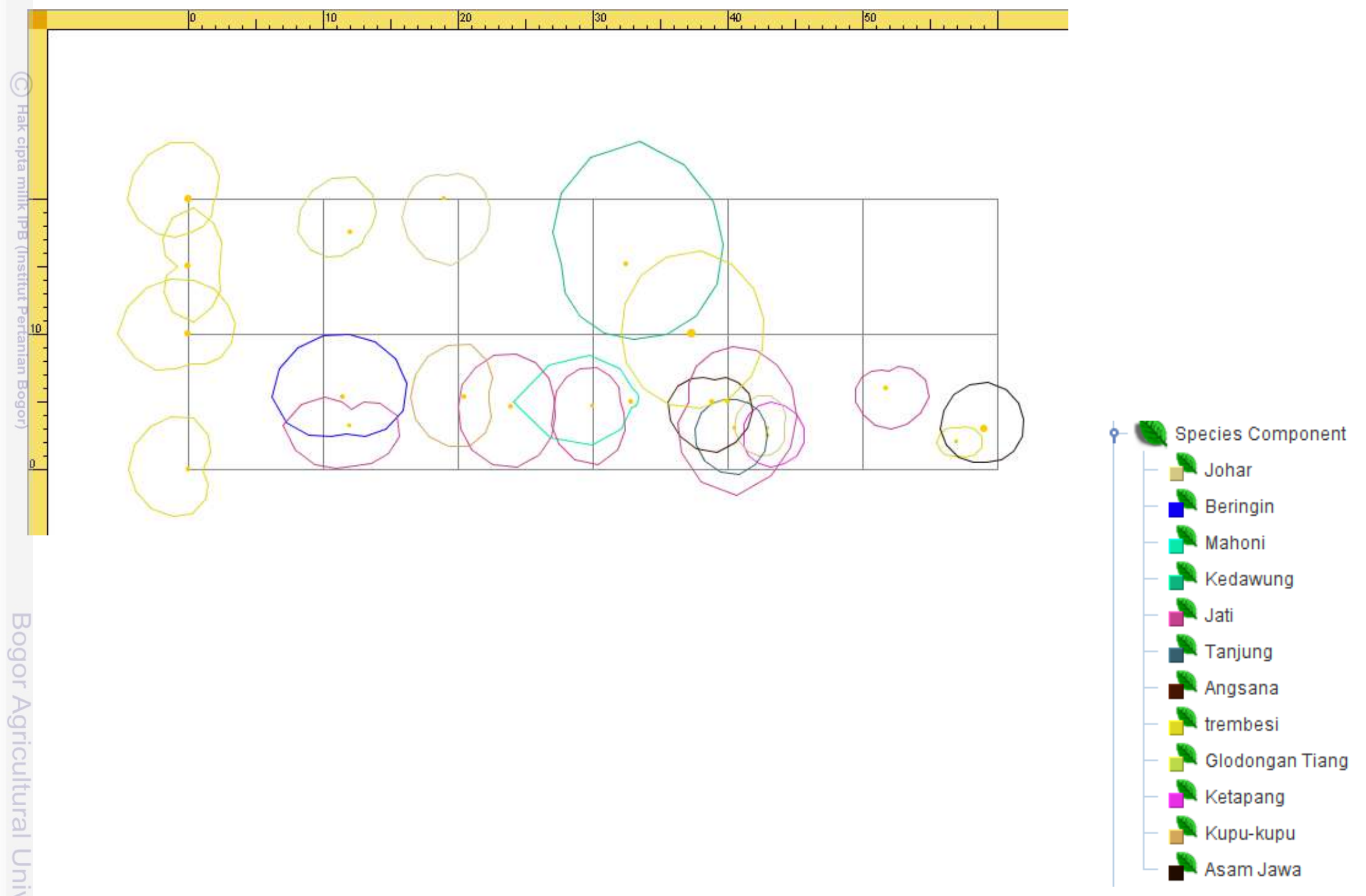




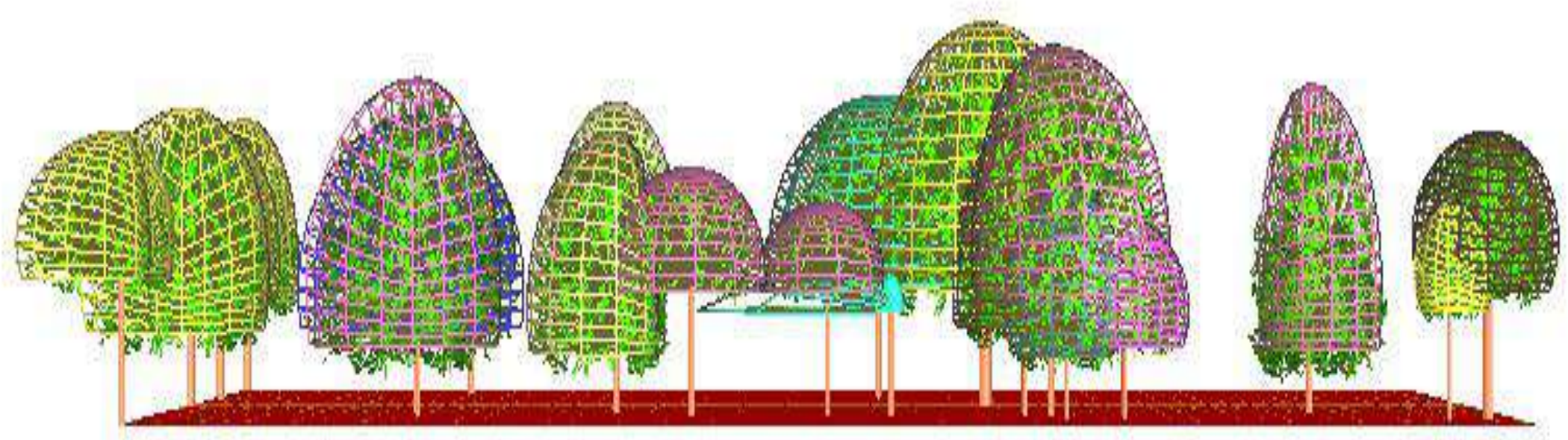

Kebun Bibit Wonorejo 


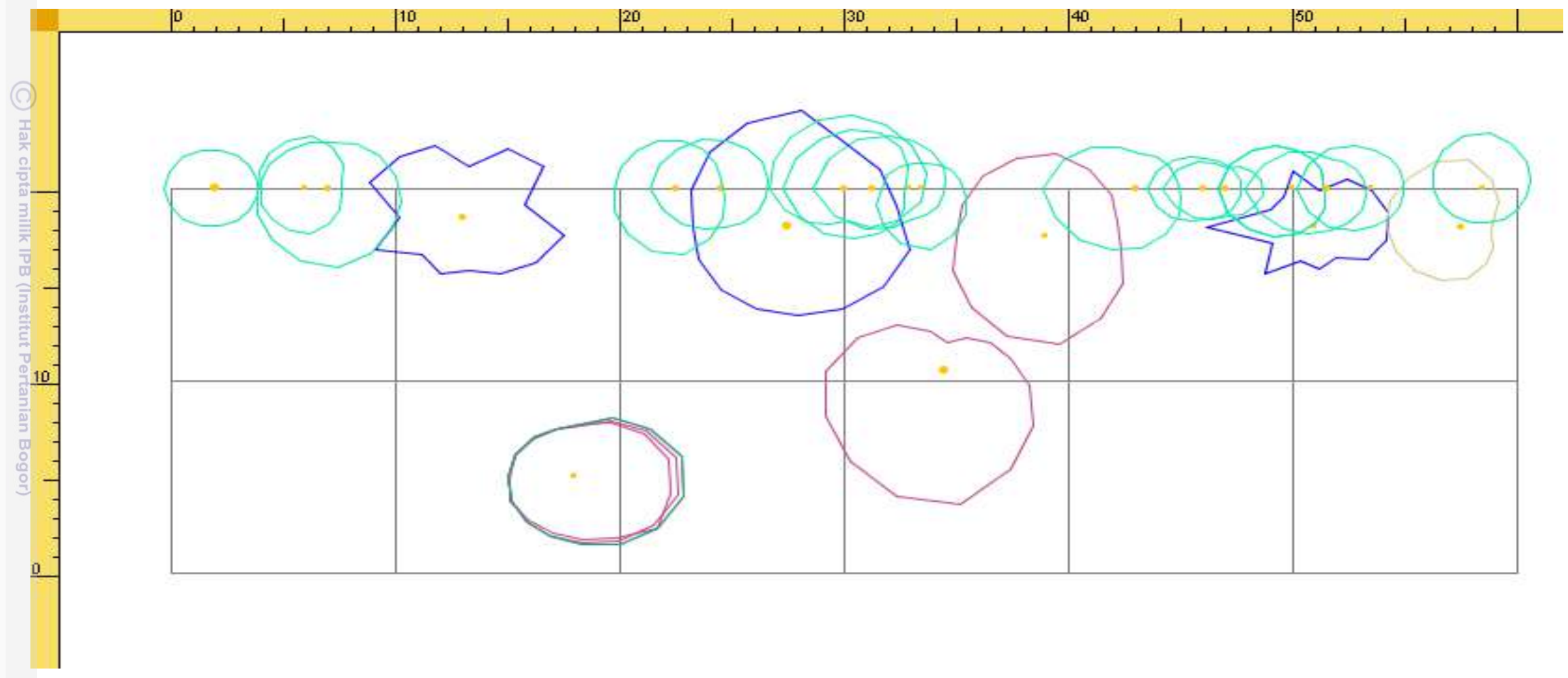


대 Trembesi

a Jabon

vambooyan

- Flamboyan 


\section{RIWAYAT HIDUP}

Penulis dilahirkan di Kota Pariaman tanggal 06 Juni 1996 dari bapak Suardi Aminsyah dan Ibu Ponniar Anis. Penulis merupakan anak kedua dari tiga bersaudara. Penulis menyelesaikan pendidikan formal di SDN 16 Kp Pauh pada tahun 2008, SMPN 1 V Koto Kp Dalam pada tahun 2011, dan SMA 2 Kota Pariaman pada tahun 2014. Penulis diterima di Departemen Konservasi Sumberdaya Hutan dan Ekowisata Institutu Pertanian Bogor pada tahun 2014 melalui jalur Seleksi Nasional Masuk Perguruan Tinggi Negeri (SNMPTN).

Penulis melakukan praktik lapang diantaranya Praktik Umum Kehutanan (PUK) di Sancang barat - Papandayan - Gunung Walat pada tahun 2016. Praktik Kerja Lapang Profesi (PKLP) di Taman Nasional Gunung Halimun Salak pada tahun 2017. Penulis aktif dalam lembaga kegiatan kemahasiswaan IPB yaitu DPM-E tahun 2017/2018 dan kegiatan Himpunan Mahasiswa Konservasi Sumberdaya Hutan dan Ekowisata (HIMAKOVA) tahun 2015-2017 sebagai anggota biro sosial dan lingkungan. Pada tahun 2016 penulis mengikuti Ekspedisi Surili HIMAKOVA di Suaka Margasatwa Rimbang Baling Riau. Pada tahun 2017 penulis mengikuti Ekspedisi Rafflesia HIMAKOVA di Suaka Alam Sancang dan ditahun yang sama penulis juga mengikuti ekspedisi Surili HIMAKOVA yang dilaksanakan di Taman Nasional Kutai, Kalimantan Timur.

Sebagai syarat untuk memperoleh gelar Sarjana Kehutanan, penulis melaksanakan penelitian di Kota Surabaya dengan judul "Nilai Kenyamanan Ruang Terbuka Hijau di Kota Surabaya" di bawah bimbingan Dr Ir Rachmad Hermawan, MScF dan Dr Yudi Setiawan, SP, M.Env. Sc. 